\title{
Impact of HMGB1, RAGE, and TLR4 in Alzheimer's Disease (AD): From Risk Factors to Therapeutic Targeting
}

\author{
Yam Nath Paudel ${ }^{1, *}$, Efthalia Angelopoulou ${ }^{2}$, Christina Piperi ${ }^{2, *}$, Iekhsan Othman ${ }^{1}$ (D), \\ Khurram Aamir ${ }^{3}$ and Mohd. Farooq Shaikh $1, *$ (D) \\ 1 Neuropharmacology Research Laboratory, Jeffrey Cheah School of Medicine and Health Sciences, \\ Monash University Malaysia, Bandar Sunway, Selangor 46150, Malaysia; iekhsan.othman@monash.edu \\ 2 Department of Biological Chemistry, Medical School, National and Kapodistrian University of Athens, \\ 11527 Athens, Greece; angelthal@med.uoa.gr \\ 3 School of Pharmacy, Faculty of Health and Medical Sciences, Taylor's University, Subang Jaya 47500, \\ Malaysia; khurramaamir@sd.taylors.edu.my \\ * Correspondence: yam.paudel@monash.edu (Y.N.P.); cpiperi@med.uoa.gr (C.P.); farooq.shaikh@monash.edu \\ (M.F.S.); Tel.: +60-182760825 (Y.N.P.); +30-210-7462610 (C.P.); +60-3-5514-4483 (M.F.S.); \\ Fax: $+30-210-7462703$ (C.P.)
}

Received: 28 November 2019; Accepted: 4 February 2020; Published: 7 February 2020

\begin{abstract}
Alzheimer's disease (AD) is a devastating neurodegenerative disorder and a leading cause of dementia, with accumulation of amyloid-beta (A $\beta$ ) and neurofibrillary tangles (NFTs) as defining pathological features. AD presents a serious global health concern with no cure to date, reflecting the complexity of its pathogenesis. Recent evidence indicates that neuroinflammation serves as the link between amyloid deposition, Tau pathology, and neurodegeneration. The high mobility group box 1 (HMGB1) protein, an initiator and activator of neuroinflammatory responses, has been involved in the pathogenesis of neurodegenerative diseases, including AD. HMGB1 is a typical damage-associated molecular pattern (DAMP) protein that exerts its biological activity mainly through binding to the receptor for advanced glycation end products (RAGE) and toll-like receptor 4 (TLR4). RAGE and TLR4 are key components of the innate immune system that both bind to HMGB1. Targeting of HMGB1, RAGE, and TLR4 in experimental AD models has demonstrated beneficial effects in halting AD progression by suppressing neuroinflammation, reducing $A \beta$ load and production, improving spatial learning, and inhibiting microglial stimulation. Herein, we discuss the contribution of HMGB1 and its receptor signaling in neuroinflammation and $\mathrm{AD}$ pathogenesis, providing evidence of its beneficial effects upon therapeutic targeting.
\end{abstract}

Keywords: HMGB1; Alzheimer's disease; RAGE; TLR4; Neuroinflammation

\section{Introduction}

Alzheimer's disease (AD) is a progressive complex neurodegenerative disorder and an emerging global health concern, afflicting around 50 million worldwide [1]. AD can be described by a steady decline in cognitive function leading to dementia in aging population. The neuropathological hallmarks of $\mathrm{AD}$ include acquisition of amyloid- $\beta(\mathrm{A} \beta)$ peptide into the amyloid plaques and intraneuronal neurofibrillary tangles (NFTs), comprising of accumulated Tau protein due to hyper- and/or abnormal phosphorylation [2].

AD occurs in two major forms, known as sporadic AD and familial AD. The former is most common ( $90 \%$ of $\mathrm{AD}$ cases), affecting people of any age, but mainly above the age of 65 years and it is often referred as late-onset AD (LOAD) [3]. The aetiology of sporadic AD is not well understood, but 
it has been associated with several genetic, environmental, and lifestyle factors [4]. On the contrary, familial AD is a less prominent form, with an earlier onset. Familial AD has been associated with mutations in three major genes: $\mathrm{A} \beta$ precursor protein (APP), presenilin1 (PSEN1), and presenilin 2 (PSEN2), which induce abnormal overproduction of $\mathrm{A} \beta$ [5].

Currently, the available AD drugs provide only symptomatic relief without altering the disease progression, thus reflecting the pressing need of effective and safe disease modifying therapies for AD. Most treatment efforts have been focused on modulation of $A \beta$ accumulation mainly through gamma-secretase inhibition, passive vaccination, or amyloid immunotherapy [6], but with poor clinical outcomes [7].

The repeated failure of AD clinical trials has shifted drug development towards neuroinflammation, which serves as the link between amyloid deposition, Tau pathology, and neurodegeneration [8]. Among several mediators, high mobility group box 1 (HMGB1) protein has been involved in the initiation and activation of neuroinflammatory responses under pathological conditions. HMGB1 protein is the only family member that has been abundantly and most ubiquitously expressed [9] out of the four proteins (HMGB1, HMGB2, HMGB3, and HMGB4), gaining increased attention in recent time. HMGB1 protein is composed of a chain of 215 amino acids with a molecular weight of $25 \mathrm{kDa}$, comprising of two DNA binding domains (Box A and Box B) and a negatively charged C-terminal $[10,11]$. HMGB1 exists in three isoforms (fully reduced HMGB1, sulfonyl HMGB1, and disulfide HMGB1). However, disulfide HMGB1 is the only isoform exhibiting pro-inflammatory cytokine-like activity [12]. The functions of HMGB1 mainly depend on its location, binding partners, and redox states $[13,14]$.

HMGB1 functions as an archetypal alarmin and a typical damage-associated molecular pattern (DAMPs) molecule [15]. Alarmins, being endogenous molecules that can be released into the extracellular settings upon cellular stress or damage, have been shown to activate the immune system [16]. The most well-known alarmins include HMGB1, S100s, heat shock proteins (HSPs), IL-1a, uric acid, cathelicidins, defensins, and thymosins [17]. HMGB1 acts as a chemotactic or pro-inflammatory mediator through direct binding to the receptor for advanced glycation end products (RAGE) and toll-like receptor-4 (TLR4) [11]. RAGE plays a significant role in neurodegeneration, whereas TLR4, being an immune cell receptor, regulates immune response [18]. Both receptors share common signaling pathways to induce inflammation [11] and they have been implicated in the pathogenesis of several diseases with therapeutic targeting potential [12].

Accumulative evidence highlights the pathogenic role of HMGB1, RAGE, and TLR4 signaling in AD onset. Upregulation of HMGB1, RAGE, and TLR4 protein levels has been detected in AD peripheral samples [19-21]. Moreover, elevated HMGB1 expression was detected in hippocampal neuronal cells of the $A \beta_{25-35}$-induced AD-related model of neuroinflammation and has been correlated with AD progression [18]. In addition, activation of RAGE signaling in AD has been implicated in the production and aggregation of $A \beta$, NFTs formation, disruption of synaptic transmission, and neuronal degeneration [22]. At the same time, TLR4 activation has been implicated in the induction of neuroinflammation and $\mathrm{A} \beta$ deposition [23].

Herein, we discuss the pathogenic role of HMGB1 and its principal receptors in AD pathology along with their biomarker potential and the promising clinical outcome of blocking/inhibiting HMGB1, RAGE, and TLR4 in AD experimental studies.

\section{The Pivotal Role of Neuroinflammation in AD Onset}

Neuroinflammation has emerged as an important feature of $A D$, presenting a link between accumulation of $A \beta$ and NFTs [24]. It has been associated with $A D$ progression through the activation of astrocytes and microglia, and may present both a driving factor of the disease as well as a response to pathogenic events [25].

There is evidence that inflammation, along with sustained activation of microglia and other immune cells, takes place in $\mathrm{AD}[24,26,27]$. $\mathrm{A} \beta$ presence has been shown to induce microglial release of pro-inflammatory cytokines and initiation of APP production, leading to increased 
$A \beta$ production [28,29]. It is possible that neuroinflammation has an additive effect and serves as a risk factor that increases disease severity by exacerbating $A \beta$ and Tau pathology [24]. Its presence has been associated with several other neurodegenerative dementias, including Parkinson's disease dementia (PDD), frontotemporal dementia (FTD), and Lewy body dementia (LBD) [30]. Enhanced neuroinflammation due to overexpression of pro-inflammatory cytokines has been previously involved in the elevation of hyperphosphorylated Tau and in the decline of hippocampal function [31].

In this context, HMGB1 has been demonstrated to mediate neuroinflammation, and participate in the process of neurodegeneration [32,33]. These data suggest that development of novel pharmacological modulators that can modulate HMGB1 and its receptors (RAGE and TLR4) and control or reduce neuroinflammation may present additional therapeutic strategies to current AD treatment.

\section{Evidence of HMGB1 Implication in AD Pathogenesis}

HMGB1 is a DNA binding protein localized in the nucleus that translocates to the cytoplasm and eventually is released to the extracellular space during cell activation and apoptosis. Upon stimulation, HMGB1 undergoes post-translational modifications (PTMs) and, based on the redox status of cysteine residues (at positions 23,45 , and 106), it can initiate cytokine production via TLR4 or induce chemotaxis through its interaction with chemokine CXCL12 [34,35]. When released extracellularly, HMGB1 becomes a double-edged sword during neural development and neurodegeneration [33].

Recent studies indicate the activation of HMGB1 in AD experimental models. HMGB1 was found localized in the nucleus and the cytoplasm of hippocampal neuron cultures, in $A \beta_{25}-35$-induced AD-related model of neuroinflammation. Upon $A \beta_{25-35}$-treatment, a higher expression of RAGE and TLR4-NF-kB (at mRNA and protein level), along with inflammatory mediators (HMGB1, IL-1 $\beta$, IL-6, and TNF- $\alpha$ ), was observed in hippocampal neuronal cells. This finding strongly suggests that neuroinflammation is a crucial contributor of AD and implicates HMGB1 in mediating AD pathogenesis through activation of RAGE/TLR4 signaling, being correlated with AD progression [18].

Treatment of mouse microglial (N9) cell line with A $\beta(1000 \mathrm{nM})$ was shown to upregulate HMGB1, IL-1 $\beta$, and nod-like receptor protein 3 (NLRP3)-inflammasome, indicating a plausible contribution to microglial activation and subsequent inflammation in $\mathrm{AD}$ [36]. This is further confirmed by the fact that dipeptidyl vinyl sulfone attenuates $A \beta$-induced activation of inflammatory process as evident from downregulation of HMGB1, NLRP3, and IL-1 $\beta$, indicating a reduction of A $\beta$-induced microglial activation as an emerging approach against $\mathrm{AD}[36]$.

In an animal model of early AD monitoring, using 5xFAD transgenic mice, HMGB1 was shown to initiate neurite degeneration with TLR4-myristoylated alanine-rich C-kinase substrate (MARCKS), triggering MARCKS phosphorylation [37]. In fact, HMGB1 initiated neurite degeneration independent of $A \beta$ and the process of $A \beta$ aggregation by disrupting the balance between different $A \beta$ isoforms [37]. HMGB1 was released from necrotic neurons with intracellular $A \beta$, thus proposing that HMGB1 occurs downstream of the established intracellular $A \beta$ toxicity. The association between HMGB1 and A $\beta$ is therefore bi-directional and HMGB1 may be considered as an independent AD mediator, closely related to the amyloid cascade [37].

The impact of extracellular HMGB1 in the microglial phagocytosis of $A \beta 40$ and $A \beta 42$ has been explored in the perspective of $A D[38,39]$. A HMGB1 injection with $A \beta 42$ impeded the $A \beta 42$ clearance from the ipsilateral rat hippocampus. $A \beta 42$-induced neurodegeneration was also increased by extracellular HMGB1. Moreover, by inhibiting the microglial phagocytosis, HMGB1 enhanced A $\beta$ mediated neurotoxicity and stabilized the formation of $A \beta$ monomers [38], suggesting its pathogenic role. Therefore, inhibition of extracellular HMGB1 might be a potential therapeutic approach against AD.

A previous study demonstrated the binding affinity between HMGB1 and A $\beta 40$, where the combination of HMGB1 with $A \beta$ and $A \beta 40$ was immunoprecipitated with A-Sepharose-linked antibodies against HMGB1 or A $\beta$ [39]. Mechanistically, extracellular HMGB1 might act as a chaperone for $A \beta$ and reduce the microglial $A \beta$ clearance by interfering with $A \beta 40$ degradation and $A \beta 42$ internalization by microglia. Therefore, extracellular HMGB1 was found to attenuate microglial A $\beta$ 
clearance and possibly contribute to AD progression [39] by interacting with RAGE and TLR4 that are involved in microglial $\mathrm{A} \beta$ phagocytosis $[40,41]$.

The p35-/ $/ \mathrm{Tg} 2576(\mathrm{KO} / \mathrm{Tg}$ ) mice model of AD with the deletion of $\mathrm{p} 35$ (a neuronal activator of CDK5) exhibited synaptic dysfunction and increased neuronal cell death, which is correlated with activated microglial infiltration and upregulated HMGB1 expression. Importantly, microglial infiltration in the dentate gyrus (DG) and CA1 led to increased HMGB1 secretion, which might increase neuronal apoptosis when combined with $A \beta$ [42]. Therefore, blocking HMGB1 expression may provide protection against neuronal cell death.

Despite several studies on adult hippocampal neurogenesis (AHN) in AD [43,44], no similar conclusion or mechanisms of regulation have been identified [45]. This is evident of the controversial studies that showed AD to downregulate hippocampal neurogenesis with progression of disease [46] or to increase hippocampal neurogenesis [47]. Nevertheless, disruption of AHN at early stages might mediate the AD pathogenesis, indicating a therapeutic approach towards its prevention and treatment [48].

In this regard, HMGB1 has emerged as an inducer of differentiation of neural progenitor cells (NPCs). A study using TgCRND8 mice (an animal model of FAD) demonstrated no significant growth of new mature neurons in the hippocampi when compared to WT mice, indicating decreased survival and/or integration of newborn neurons. Of importance, HMGB1 and A $\beta_{1-42}$ activated a potential reparative mechanism by promoting neuronal differentiation of adult hippocampal NPCs via the activation of the RAGE/NF- $\kappa B$ cascade [49], thus demonstrating the pro-neurogenic potential of HMGB1. It is therefore evident that HMGB1 activation in AD occurs through the interaction with $A \beta$ and that it is not only a risk factor but may also exert a restorative effect in AHN.

Disruption of learning and memory represents important hallmarks of $\mathrm{AD}$ and intracerebroventricular (ICV) injection of HMGB1 $(10 \mu \mathrm{g})$ in WT, TLR4 ${ }^{-/}$, and $\mathrm{RAGE}^{-/}$mice was shown to block these functions. The HMGB1 injection was found to affect memory encoding, as demonstrated by reduced novel object preference index in novel object recognition test (NORT). The HMGB1 amnesic effect was mediated by RAGE and TLR4, as evident by the blockade of memory impairment upon injection of TLR4 antagonist in RAGE-deficient mice [50].

\section{Implication of RAGE in AD}

RAGE belongs to the immunoglobulin (Ig) superfamily [51] and is widely expressed on several cell types, ranging from vascular cells (endothelial and smooth muscle cells) to immune/inflammatory cells (neutrophils, monocytes/macrophages, lymphocytes, and dendritic cells) [52-55]. RAGE binds to several DAMPs (including AGEs, HMGB1, S100s, and DNA) and mediates differential cellular responses, being a crucial regulator of the innate immune response. Due to its ability to identify a range of structurally unrelated endogenous and exogenous ligands, RAGE is regarded as a pattern recognition receptor (PRR) [56]. The PRRs comprise of TLRs, nucleotide-binding oligomerization-like receptors, and several other DNA sensors.

There is evidence that RAGE signaling is implicated in an array of inflammatory [57] and neurodegenerative diseases [58], including $\mathrm{AD}[22,59]$. Amyloid plaques in $\mathrm{AD}$ develop due to the overproduction of $A \beta$ and/or the failure of $A \beta$ clearance, promoting its deposition. Of importance, RAGE has been demonstrated to play a crucial role in $A \beta$ production and at the failure of $A \beta$ clearance [22]. RAGE, due to its molecular structure and nature, facilitates circulating plasma $A \beta$ entry into the brain through BBB [60]. Along with its decoy receptor soluble RAGE (sRAGE), they may confer protection against $A D$ pathogenesis by manipulating the transport of $A \beta$ into the brain or by modulating the inflammatory mechanisms [61]. sRAGE, an isoform of RAGE lacking the transmembrane domain, competes with the cell-surface RAGE for ligand binding, and has been shown to be involved in the removal or neutralization of circulating ligands, acting as a decoy molecule [61].

RAGE activation induces $A \beta$ production and the aberrant hyperphosphorylation of Tau. It can activate microglia and astrocytes in a reactive as well as in an inflammatory state, thus aggravating 
AD pathogenesis by inducing a cycle of inflammation and cellular stress [62]. In a cross-sectional clinical study of different dementia patient types, the levels of AGEs and its receptor RAGE were found upregulated in AD, whereas the levels of sRAGE were decreased, indicating that AGE, RAGE, and sRAGE might contribute to AD pathology [63].

In a clinical study of AD and non-demented (ND) patients, the upregulation of RAGE levels in the hippocampus and inferior frontal cortex in post-mortem $\mathrm{AD}$ patients was correlated with the severity of brain pathology. Increased immunoreactivity of RAGE has been observed mainly in neurons, microglia, and astrocytes in the affected areas of AD patients [40]. An earlier clinical study unraveled that microvascular RAGE levels were increased with AD onset and were upregulated consecutively in relation to AD severity. In concert, a significant upregulation in endothelial RAGE immunoreactivity was observed in severe Braak V-VI AD patients compared to aged-controls, as well as in patients with early AD pathology. Similarly, a notable elevation in endothelial RAGE immunoreactivity was observed in patients exhibiting early AD-like symptoms compared to aged controls with no reported AD pathology [64].

RAGE has also been demonstrated as a modulating cofactor of the $A \beta$ impact on neuronal function. An experimental study investigating the effects of RAGE in an A $\beta$-rich environment employed a transgenic ( $\mathrm{Tg}$ ) mouse model with targeted neuronal overexpression of RAGE and mutant APP (mAPP). Double Tg mice (mutant APP/RAGE) exhibited early spatial learning and memory impairments, supplemented by an altered activation of synaptic plasticity markers (CREB and MAPK) and amplified neuropathologic findings, before the detection of these alterations in mAPP mice [65]. On the contrary, when Tg mice with a dominant-negative RAGE construct targeted to neurons were crossed with mAPP animals, protection of spatial learning/memory deficits and reduced neuropathological changes were observed. These findings suggest that RAGE acts as a cofactor for $A \beta$-mediated neuronal perturbation in experimental models, with a potential as a therapeutic target to improve cellular disruption [65].

Similarly, Tg mice expressing mAPP in neurons and RAGE in microglia showed increased production of IL- $1 \beta$ and TNF- $\alpha$, enhanced infiltration of microglia and astrocytes, A $\beta$ aggregation, decreased AChE activity, and rapid disruption of spatial learning/memory [66]. RAGE-facilitated generation of pro-inflammatory mediators enhanced accumulation of $A \beta$ via a positive feedback loop, activating the RAGE receptor that will ultimately exacerbate neuroinflammation and amyloid pathology [66]. Earlier studies investigating mAPP mice with genetic deletion of RAGE (mAPP/RO) have shed more light on the impact of RAGE on accumulation of $A \beta$, amyloid pathology, learning and memory impairments, indicating that an additional underlying mechanism is a part of its role in the cleavage of APP to release A $\beta$ [67]. The cytosolic domain of neuronal RAGE was implicated in the abnormal APP processing and A $\beta$ production via the enhancement of $\beta$ - and $\gamma$-secretase activity. The deletion of RAGE was found to block the initiation of GSK3 $\beta$ and p38 MAPK signaling axis in the $A \beta$ milieu of mAPP mice. Furthermore, RAGE deficiency conferred a defensive effect on the learning and memory deficits in mice overexpressing mutated APP [67]. These findings further support the benefits of targeting RAGE to block the aberrant APP-A $\beta$ metabolism and hinder AD progression.

Overall, there are several RAGE-related signaling axes including the RAGE/ $\mathrm{Ca}^{2+} / \mathrm{calmodulin}^{-}$ dependent protein kinase kinase- $\beta$ (CaMKK- $\beta$ )-AMPK, the RAGE/extracellular signal regulated kinase $1 / 2$ (ERK1/2), RAGE/GSK-3 $\beta$, and RAGE/NF-KB that have been implicated in AD, which are all associated with the regulation of abnormal Tau hyperphosphorylation and $A \beta$ pathology [22].

\section{TLR4 Involvement in AD Pathogenesis}

TLRs belong to the family of microbe-sensing receptors and contribute to innate immune defense against infection through binding to microbial molecules [68]. To date, 10 TLRs located either at the cellular surface (TLR1, TLR2, TLR 4, TLR5, TLR6, and TLR10) or in the endosome (TLR3, TLR7, TLR8, and TLR 9) have been reported [69]. TLR4 is a transmembrane protein that belongs to the PRRs family [70], which is widely explored in the context of AD pathology. The binding of 
pathogen-associated molecular patterns (PAMPs) to TLR4 activates the NF- $\mathrm{kB}$ signaling axis, resulting in the synthesis and secretion of inflammatory cytokines [71]. Due to the known contribution of the innate immune system in AD, TLR4 has received increased attention and has been extensively studied in AD [72]. TLR4 is also instrumental in driving the binding of fibrillary amyloid and its phagocytosis by microglia in $\mathrm{AD}$ [73]. The presence of amyloid is detrimental in activating the TLR4-mediated NF- $\mathrm{BB} / \mathrm{MAPK}$ inflammatory axis, promoting the discharge of pro-inflammatory and neurotoxic cytokines (IL-1 $\beta$, IL-6, and TNF- $\alpha$ ) [23,74]. Importantly, microglial activation by A $\beta$ has been shown to require a functional receptor complex of TLR4, MD-2, and CD14 [23].

Additionally, loss-of-function mutations of the TLR4 gene have been associated with inhibition of microglial and monocytic activation by accumulated amyloid peptide, leading to a decreased expression of the inflammatory markers (IL- 6 and TNF- $\alpha$ ) and nitric oxide, implicating TLR4 in the neuroinflammation of $\mathrm{AD}$. Moreover, TLR4 mRNA was found elevated in APP-overexpressing mice. TLR4 was also shown to mediate $A \beta$-induced microglial neurotoxicity, as well as $A \beta$-mediated activation of murine microglia and human monocytes [23].

Despite the fact that innate immune/inflammatory responses contribute to the AD pathology, the underlying mechanism is not completely understood. In a study investigating the contribution of TLR4 in A $\beta$-induced upregulation of cytokines and chemokines, $A \beta$-induced microglial and astrocytes stimulation, and migration of leukocytes, there was an upregulation of TNF- $\alpha$, IL-1 $\beta$, IL-10, and IL-17 levels in the brain of TLR4 WT AD mice. However, elevation of these cytokines was not reported in TLR4-mutant AD mice as compared to the TLR4-mutant non-transgenic littermates. In addition, the expression levels of the microglia marker $\mathrm{CD} 11 \mathrm{~b}$ and the reactive astrocyte marker GFAP were upregulated in the brain of TLR4-mutant AD mice compared to TLR4-WT AD mice, without difference at the levels of the common leukocyte antigen CD45. This TLR4-dependent upregulation of cytokines in the AD mouse model indicates the involvement of TLR4 signaling in disease progression and its potential therapeutic targeting [75].

The triggering receptor expressed on myeloid cells 2 (TREM2) protein, a crucial innate immune receptor in the brain, behaves as a protective mechanism against AD where TLRs play a significant role. TREM2 overexpression was associated with upregulation of the cellular activity of $A \beta_{1-42}$, and promoted its clearance by BV-2 cells, while it decreased the expression of inflammatory markers (IL-1 $\beta$, IL-6, and TNF- $\alpha$ ). It also contributed to decreased expression of other members of TLR family in BV-2 cells, such as TLR4, TLR2, and TLR6 [76]. Overall, TREM2 was shown to attenuate $A \beta_{1-42}$-mediated neuroinflammation in BV-2 cells via downregulation of TLR signaling pathway. TLR4-driven inflammation was further negatively controlled by TREM2 [77]. Lipopolysaccharide (LPS) injection into the APP/PS1 transgenic AD model mimics systemic inflammation in the development of $\mathrm{AD}$ whereby TLR4 expression was upregulated. On the contrary, expression of TREM2 was markedly decreased in APP/PS1 mice, reflecting that the negative modulatory effect of TREM2 on inflammation could be inhibited by LPS-induced hyperactive TLR4. Thus, an imbalance of TLR4/TREM2 may present a potential link between $\mathrm{AD}$ and systemic inflammation [78].

In a clinical study of post-mortem human brains, an upregulation of the TLR4, IL-6, and TNF- $\alpha$ mRNA levels was observed at the frontal cortex of AD subjects as compared to age-matched controls [21]. Similarly, in a mouse model of hippocampal differentiation (at 7 days post-lesion) without amyloidosis (i.e., the entorhinal cortex lesioned mouse), hippocampal TLR4 and IL-1 $\beta$ mRNA expression levels were significantly elevated compared to sham-lesioned mice. However, during reinnervation phase (at 21 days post-lesion) there was no significant difference at the TLR4, IL-1 $\beta$, IL-6, and TNF- $\alpha$ mRNA levels compared to sham-lesioned mice [21]. This finding suggests that the contribution of TLR4 in neuroinflammatory process during $\mathrm{AD}$ is not only triggered by amyloidosis, but also by an amyloid independent differentiation process that occurs in the early phases of the disease [21].

A study investigating the role of TLR4 signaling and microglial activation in early stages of AD pathology reported that a non-functional mutation in the TLR4 gene reduced $A \beta$-induced activation of microglia in the AD mice model at 5 months of age, when the brain deposits of $A \beta$ usually 
increase. In fact, no difference was noted in the cerebral $A \beta$ deposits and buffer-soluble $A \beta$ amounts between TLR4 wild-type (TLR4W Tg) and TLR4 mutant AD (TLR4M Tg) mice at the early stages of $\beta$-amyloidosis [79]. This finding indicates that TLR4 signaling does not alter the production of $A \beta$ and the onset of $A \beta$ deposition. On the contrary, the 9-month-old TLR4M Tg mice exhibited an elevation in the quantity of cerebral $\mathrm{A} \beta$ deposits and soluble $\mathrm{A} \beta 42$, associated with special learning impairment and decreased CCL3 expression, suggesting that microglial activation via TLR4 could be neuroprotective [79].

Furthermore, the TLR signaling axis contributes to the clearance of A $\beta$-deposits in the AD brain. The contribution of TLR4 in amyloidogenesis has been revealed in vivo. The Mo/Hu APPswe PS1dE9 mice, which are homozygous for a destructive mutation of TLR4 (Tlr ${ }^{\text {Lps-d }} /$ Tlr $^{\text {Lps-d }}$ ), showed increased diffuse and fibrillar A $\beta$ deposits compared to TLR4-WT mouse models [41], indicating that manipulation of the innate immune responses via the TLR4 axis may decrease A $\beta$ load and cell injuries in AD brain.

LPS was shown to activate a greater number of microglia in the young TgAPP/PS1 mice (without A $\beta$ deposition) compared to young WT mice, whereas its ability to activate microglia in old TgAPP/PS1 mice is less prominent (with $\mathrm{A} \beta$ deposition) as compared to old WT mice. TLR4 signaling is disrupted in TgAPP/PS1 mice, explaining the remarkable contrast in TLR4 signaling activation between WT and TgAPP/PS1 mice, as well as before and after A $\beta$ deposition in the brain [80]. Hence, microglial TLR4 signaling is inhibited in the AD mouse model, indicating that dysregulated TLR4 signaling may be associated with $\mathrm{A} \beta$ accumulation in the brain [80].

The relationship between neuroinflammation, autophagic activity, and TLR4 stimulation has also been investigated in Tau transgenic AD mice. TLR4 stimulation through LPS injection triggers microglial/macrophage inflammatory activation, further enhancing the autophagic flux in the mouse brain. Moreover, chronic mild TLR4 stimulation improves AD-related pathology, as well as synaptic impairments, in Tau-transgenic mice [81].

Activation of TLR signaling can further aggravate AD via initiation of the inflammatory process, $\mathrm{A} \beta$ deposition, and oxidative stress [82]. TLR4 is not only essential for regulation of the inflammatory process, but also for the uptake as well as the phagocytic elimination of A $\beta$ plaques [41]. TLR4 activates the phagocytosis of $A \beta$ peptides [73,83], as well as contributes to the formation of $A \beta$ plaque $[84,85]$.

Taken all together, it is evident that modulation of TLR4 signaling pathways could exert a significant impact on AD pathology, mainly by changing the inflammatory state of microglia/macrophages [86].

\section{HMGB1, RAGE, and TLR4 as Potential Clinical Biomarkers of AD}

$\mathrm{AD}$ is a multifactorial disease that develops gradually with symptoms progressing with time, reflecting the need for early intervention [87]. In this regard, exploring biomarkers in AD that can predict the disease and monitor its progression while providing insight into the outcome of therapy are needed. The cerebrospinal fluid (CSF) levels of $A \beta$, fragments, and $p$-Tau or total-Tau are extensively used biomarkers for AD [88,89], but their diagnostic accuracy varies between different centers [90]. Furthermore, there is a growing interest in exploring biomarkers of AD that relate to neurodegeneration and BBB dysfunction [91]. This section focuses on novel potential AD biomarkers which are well implicated in AD pathology, such as HMGB1 and its principal receptors (RAGE and TLR4).

A clinical study validating the non-invasive clinical biomarkers of BBB dysfunction and neuroinflammation to evaluate the progression towards neurodegeneration in mild cognitive impairment (MCI) and AD patients detected upregulated expression and/or release of serum HMGB1 and sRAGE, correlated with $A \beta$ levels in AD patients [92]. Interestingly, the elevation of serum HMGB1 levels was observed in patients with MCI as compared to controls or AD patients. Moreover, soluble thrombomodulin (sTM) antigen (a marker of BBB disruption) activity was significantly upregulated in MCI and AD patients. These findings suggest that HMGB1 and sRAGE may act as clinical biomarkers for AD progression [92]. A similar type of upregulation was also reported in the brain tissues of AD patients, suggesting that HMGB1 might accumulate in either extracellular or intracellular regions [19]. 
Detection of HMGB1 on $A \beta 40$ plaques in $A D$ brains using a specific anti-A $\beta 40$ antibody demonstrated that HMGB1 accumulates extracellularly on $A \beta$ plaques containing $A \beta 40$ in AD brains [39]. A similar type of HMGB1 immunoreactivity was noted in the senile plaques, where levels of HMGB1 protein were found upregulated in AD brains [38]. Evaluation of the HMGB1 concentrations in the CSF of human AD patients showed that HMGB1 levels were unchanged in healthy controls and FTLD patients. However, in a group of AD patients, upregulation of HMGB1 levels was associated with a rapid progression of dementia, further suggesting that CSF levels of HMGB1 might represent a marker of neurodegenerative progression [37].

In a clinical study, RAGE was found co-localized near neuritic plaque deposits in the cells of A $\beta$-comprising blood vessels, and in endothelial, neuronal, and microglial cells in AD brain tissue at much higher concentrations compared to age-matched control-derived tissues [93]. In plasma samples of AD patients, the affinity-purified IgGs binding to fragment of RAGE were elevated by three-fold, whereas RAGE, IgG, and $A \beta$ titers were negatively correlated with cognitive status compared to control samples. However, individuals with severe cognitive impairment tend to demonstrate higher IgG titers [94]. These data suggest that the measurement of specific A $\beta$ and RAGE IgGs and/or their protein complex might represent a confirmatory test for AD or AD susceptibility [94].

Increased RAGE expression was observed in the capillaries of the AD brain as compared to controls. The significant negative correlations obtained between the $A \beta$ burden of amyloid plaques and RAGE-positive capillaries in AD brains suggest that RAGE is a crucial factor that influences A $\beta$ burden [95]. In an effort to elucidate the AD-related alterations in BBB-associated A $\beta$ receptors, RAGE immunoreactivity was detected in neurons from control hippocampi, whereas a significant reduction in neuronal RAGE immunoreactivity was observed in AD cases. However, a higher concentration of RAGE was detected in AD hippocampi as compared to controls by Western immunoblotting. These observations suggest that AD is linked with changes in the relative distribution of RAGE in the human hippocampus [96].

Significant elevation in the expression of RAGE levels was also observed in post-mortem AD patients (hippocampus and inferior frontal cortex) where the increased RAGE expressions were positively correlated with the severity of brain pathology [40]. Decreased expression levels of sRAGE, which inhibits RAGE signaling, have been reported in the plasma of patients with AD when compared to those with vascular dementia or normal controls [97].

A clinical study conducted in Northern Han Chinese populations demonstrated an increased plasma level of TLR4 in the peripheral blood mononuclear cells (PBMCs) along with elevated TLR4 mRNA and protein levels in LOAD patients compared to healthy controls [98]. On the contrary, a downregulation of TLR4 protein expression was observed in plasma/serum of AD patients who had more $A \beta$ plaques than in patients with other dementia-related diseases [99]. A population study in northern Italy including $626 \mathrm{AD}$ patients also reported that the +896A TLR4 pro-inflammatory allele was overrepresented in AD patients, suggesting that TLR4 single nucleotide polymorphism (SNP) may be a genetic marker of AD susceptibility [100].

\section{HMGB1, RAGE, and TLR4 Inhibition/Blockade as a Potential Therapy against AD}

Based on the evidence that HMGB1, RAGE, and TLR4 contribute to the pathogenesis of AD, their targeting might be instrumental in elucidating the plausible underlying mechanism associated with AD pathogenesis. Up to date, several HMGB1, RAGE, and TLR4 blocking/inhibiting strategies have demonstrated promising outcomes against $\mathrm{AD}$ on experimental studies and are discussed below.

\subsection{Effects of $H M G B 1$ Neutralization in $A D$}

The available therapeutic strategies to block/inhibit extracellular HMGB1 include anti-HMGB1 monoclonal antibody (mAb), specific HMGB1 inhibitors (glycyrrhizin and its derivatives), and HMGB1 interference (shRNA) in AD-like experimental settings. 
The therapeutic use of anti-HMGB1 antibodies against several HMGB1-mediated pathologies was mainly focused on elucidating the involvement of HMGB1 in several pathological conditions, validation of protein targets, and the efficacy of potential therapeutic approaches [101].

The therapeutic potential of anti-HMGB1 $\mathrm{mAb}$ has been recently reviewed in several HMGB1-mediated diseases including PD, epilepsy, TBI, and AD [102]. The anti-HMGB1 mAb treatment in 5xFAD mice ameliorated cognitive impairment at a similar level to WT mice. Administration of the anti-HMGB1 mAb during 1-6 and 3-6 months of age significantly decreased the DNA damage in the cerebral cortex of 5xFAD mice to the normal levels (at 6 months). However, treatment with anti-HMGB1 $\mathrm{mAb}$ did not modulate the expression of human APP in the brains of 5xFAD mice but inhibited the HMGB1-induced elevation of $A \beta$ monomers and oligomers [37]. In addition, anti-HMGB1 mAb treatment increased the microglia-specific marker, Iba1, mainly around $A \beta$ aggregates, and enhanced phagocytosis of the A $\beta$-HMGB1 complex. Anti-HMGB1 mAb further blocked HMGB1 activity with TLR4, inhibited phosphorylation of MARCKS at Ser46, and prevented neurite degeneration, indicating its beneficial effects in modifying disease progression [37].

Glycyrrhizin is a small-molecule inhibitor of extracellular HMGB1 cytokine activity [103] with the potential to penetrate BBB [104]. The neuroprotective effect of glycyrrhizin has been demonstrated in an array of neurological disorders, including epilepsy [105], TBI [106], and PD [107]. Although the therapeutic effect of glycyrrhizin has not been demonstrated in $A D$ mice with developed $A \beta$ pathology, its effects have been extensively evaluated against several AD-like pathologies such as LPS-induced neuroinflammation and cognitive deficits, as well as in surgery-induced cognitive decline. Glycyrrhizin and its derivatives have exerted promising effects mainly by inhibiting HMGB1, improving memory deficits, and reducing the levels of inflammatory cytokines [108-110]. The experimental studies with promising outcomes upon HMGB1 inhibition in AD-like pathologies are summarized in Table 1.

The complexity of HMGB1 inhibition/blockade is attributed to the existence of three different isoforms of HMGB1 with distinct and different functions [111]. Among the three HMGB1 isoforms, disulphide-HMGB1 is the only isoform possessing pro-inflammatory cytokine-like activity that activates macrophages/monocytes and other cells to produce cytokines, as well as inflammatory mediators [14]. Of importance, therapeutic targeting of HMGB1 in AD might be immature at present since it is implicated at multiple levels in the regulation of immune response, and the precise underlying mechanism of its involvement in $\mathrm{AD}$ has not been completely understood. Despite this limiting aspect, the encouraging data of HMGB1 neutralization mAb, glycyrrhizin, and its derivatives in AD-like pathologies suggest that it may present a promising target and needs further investigation [112].

\subsection{Effects of RAGE Inhibition in $A D$}

Several pre-clinical and clinical studies have reported the beneficial effects of RAGE inhibitors in AD-like conditions. Genetic blockade of RAGE in mAPP (mAPP/RO) mice exhibited decreased cerebral amyloid pathology with suppressed abnormal APP-A $\beta$ metabolism by downregulating activity of $\beta$ and $\gamma$-secretase. It also ameliorated learning and memory impairment as compared to mAPP mice [67]. Furthermore, mAPP mice deficient to RAGE (mAPP/DN-RAGE) demonstrated reduced production of $A \beta_{40}$ and $A \beta_{42}$ and lowered activity of $\beta$ - and $\gamma$-secretase as compared to mAPP mice. RAGE-deleted mAPP brain exhibited inhibition of p38 MAP kinase and GSK3 $\beta$ activity. These findings indicate the therapeutic potential of RAGE targeting based on its ability to inhibit APP-A $\beta$ metabolism and hinder the progression of AD [67]. Inhibition of neuronal RAGE could demonstrate cytoprotective effects by preserving neuronal function at early stages of the disease. This is further supported by studies of transgenic mice with a dominant-negative RAGE construct targeted to neurons crossed with mAPP animals which exhibited protection of spatial learning/memory deficits and reduced neuropathological alterations, reflecting that RAGE can improve cellular dysfunction [65].

Moreover, several HMGB1 inhibition approaches, including TTP488, sRAGE-mesenchymal stem cells (MSCs), FPS-ZM1, matrine, pentamidine, hesperidin, and linguizhugan, have revealed promising 
outcomes in experimental AD models mainly by inhibiting RAGE expression, decreasing production of $A \beta$, reducing $A \beta$ deposition, oxidative stress, and inflammatory cytokines, while improving spatial learning and memory (Table 2) [113-118].

Although pre-clinical studies of RAGE inhibition in AD strengthen the fact that RAGE might represent a potential therapeutic target, future pre-clinical and clinical studies are warranted to evaluate the safety and therapeutic efficacy of RAGE antagonists against AD [22].

\subsection{Effects of TLR4 Blockade in AD}

$A \beta$-mediated TLR4 activation actively promotes neuroinflammation in $A D$, suggesting that blockade/inhibition of TLR4 activation may suppress neuroinflammatory processes [75].

In an experimental study of immunological preconditioning with TLR4 agonist LPS, Monophosphoryl lipid A (MPL) was shown to upregulate IFN- $\beta$-positive cells and reduce hippocampal TNF- $\alpha$-positive cells of $A \beta$-treated rats. Reduction in TNF- $\alpha$ could be the result of increased IFN- $\beta$ levels via the TLR4 signaling axis [119]. The release of IFN- $\beta$ upon pre-treatment with TLR4 agonists might be a promising neuroprotective strategy against neurodegeneration in AD. Spontaneous loss-of-function mutation in the TLR4 gene suppressed activation of microglia and monocytes by aggregated Alzheimer's amyloid peptide, leading to the downregulation of inflammatory markers IL-6, TNF- $\alpha$, and NO [23]. TLR4 stimulation with detoxified ligand MPL ameliorated AD-like pathology in APPswe/PS1 mice, as evident by the reduced number and size of $A \beta$ deposits, as well as by the quantity of soluble $A \beta$ in the brain [120].

A wide range of therapeutic compounds (Table 3) have demonstrated their efficacy in animal models of AD-like pathologies, mainly by inhibiting TLR4 expression, suppressing microglial activation and pro-inflammatory cytokine levels, ameliorating learning and memory functions, inhibiting oxidative stress, and reducing apoptotic cell death and $A \beta$ load (number and size of $A \beta$ deposit) [120-126].

These findings indicate that therapeutic targeting of TLR4 may present a promising therapeutic approach for the symptomatic improvement and slowing of AD progression.

\section{Discussion and Future Implications}

$\mathrm{AD}$ is the major cause of dementia worldwide, accounting for $50-70 \%$ of all cases [127]. AD is considered as a complex disorder, with multiple molecules and several contributing factors playing a significant role [128]. At the early stages of $\mathrm{AD}$, the immune system contributes to the elimination of amyloid peptides. However, with disease progression, inability to clear toxic $\mathrm{A} \beta$ peptides along with an activation of the innate immune system might lead to the initiation of chronic inflammatory phenomena in the brain $[129,130]$. To date, there is lack of disease-modifying therapy against AD despite the tremendous research efforts, reflecting the increased complexity of the disease. There is an intensive need to explore novel therapeutic strategies that will prevent $\mathrm{AD}$ and/or retard the disease progression. However, due to the lack of precise understanding about the mechanisms underlying AD pathogenesis, the development of treatment strategies against AD is complex, which is evident by the repeated failure of drugs in the clinical trial.

Intervention at the early pathological stages of $\mathrm{AD}$ is considered of primary importance and HMGB1 with its receptors (RAGE and TLR4) has gained increased attention in AD pathogenesis (Figure 1). Upregulation of HMGB1, RAGE, and TLR4 levels in AD patients $[92,95,98]$ and experimental models [18] indicate their involvement in the disease pathogenesis, presenting a possible risk factor and a therapeutic target. 


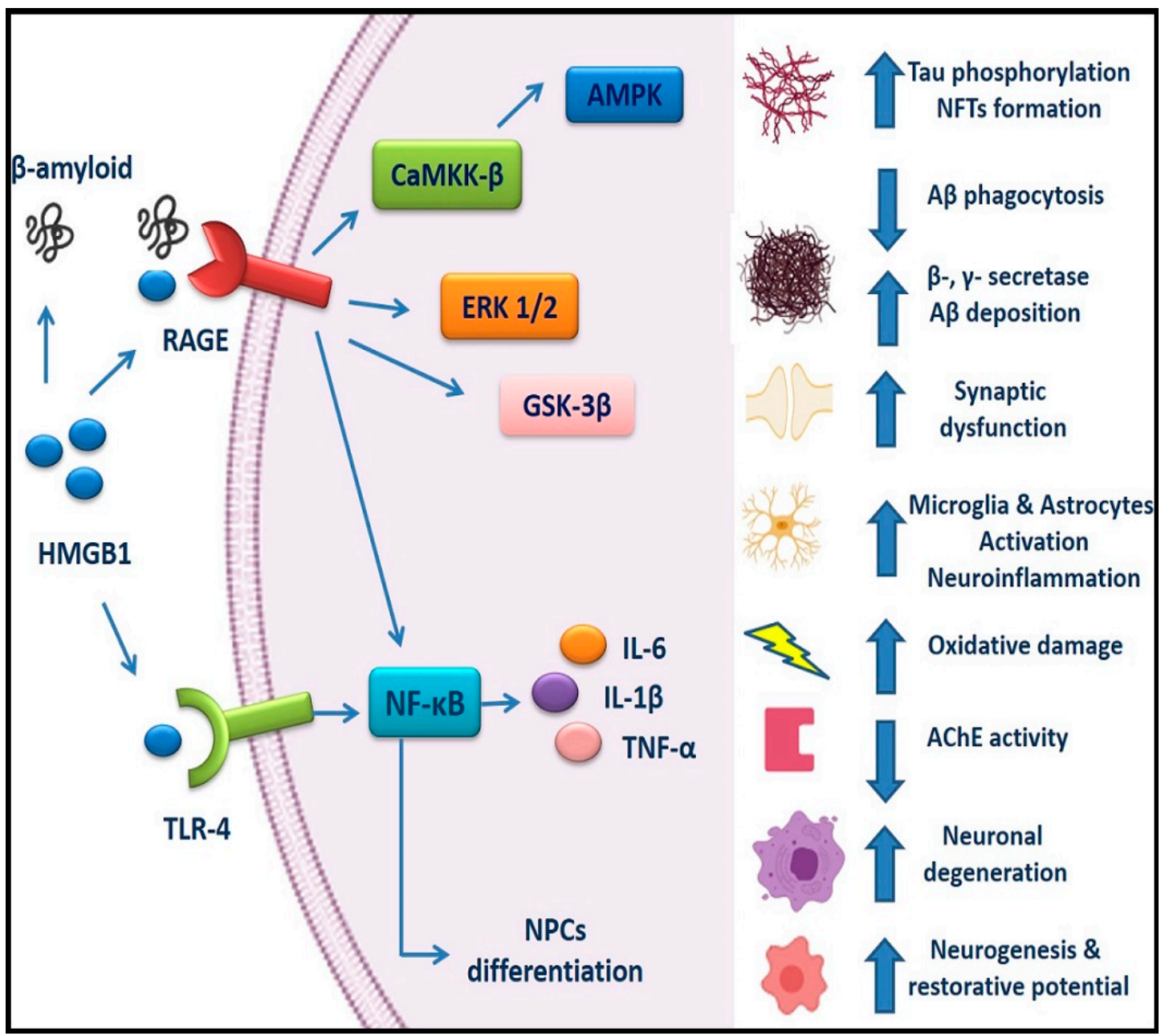

Figure 1. HMGB1/RAGE and HMGB1/TLR4 signaling pathways in AD: HMGB1 can interact with extracellular $A \beta$ peptides and decrease $A \beta$ deposition by inhibiting $A \beta$ clearance by microglia, as well as increasing $\beta$ - and $\gamma$-secretase activity. RAGE enhances production of $A \beta$, abnormal Tau hyperphosphorylation, and NFTs formation. HMGB1/RAGE and HMGB1/TLR4 signaling induce neuroinflammation by activating the NF- $\mathrm{kB}$ pathway, increasing production of pro-inflammatory cytokines including TNF- $\alpha$, IL-6, and IL-1 $\beta$, activating microglia and astrocytes in a reactive and inflammatory state, and thus aggravating the $\mathrm{AD}$ pathogenesis through a vicious cycle of inflammation and oxidative damage. RAGE/CaMKK- $\beta$-AMPK, the RAGE/ERK1/2, RAGE/GSK-3 $\beta$, and RAGE/NF- $\mathrm{BB}$ pathways have been involved in the regulation of abnormal Tau hyperphosphorylation and $A \beta$ pathology. RAGE signaling has been also implicated in synaptic dysfunction, reduced AChE activity, and neurodegeneration. However, activation of RAGE/NF- $\mathrm{kB}$ pathway by HMGB1 in adult NPCs promotes neuronal differentiation and formation of new neurons, leading to increased adult neurogenesis. In addition, HMGB1 may play dual roles in AD pathogenesis, since it can also contribute to reparative mechanisms in the AD brain. AD, Alzheimer's disease; HMGB1, High mobility group box 1; RAGE, Receptor for advanced glycation end products; TLR4, Toll-like receptor 4; A $\beta$, Amyloid beta; NFTs, Neurofibrillary tangles; CaMKK- $\beta, \mathrm{Ca}^{2+} /$ calmodulin-dependent protein kinase kinase- $\beta$; ERK1/2, Extracellular signal regulated kinase $\frac{1}{2}$; NPCs, Neural progenitor cells; IL, Interleukin; NF- $\beta \beta$, Nuclear factor $\kappa$ light chain enhancer of activated $\beta$ cells; TNF- $\alpha$, Tumor necrosis factor- $\alpha$.

Interestingly, inhibition/blockade of HMGB1, RAGE, and TLR4 in experimental AD-like pathologies demonstrated promising outcomes by modifying AD progression through suppression of neuroinflammation, reduction of $A \beta$ load (number and size of $A \beta$ deposit) and $A \beta$ production, improvement of spatial learning and inhibition of microglial activation (Figure 2) (Tables 1-3). 


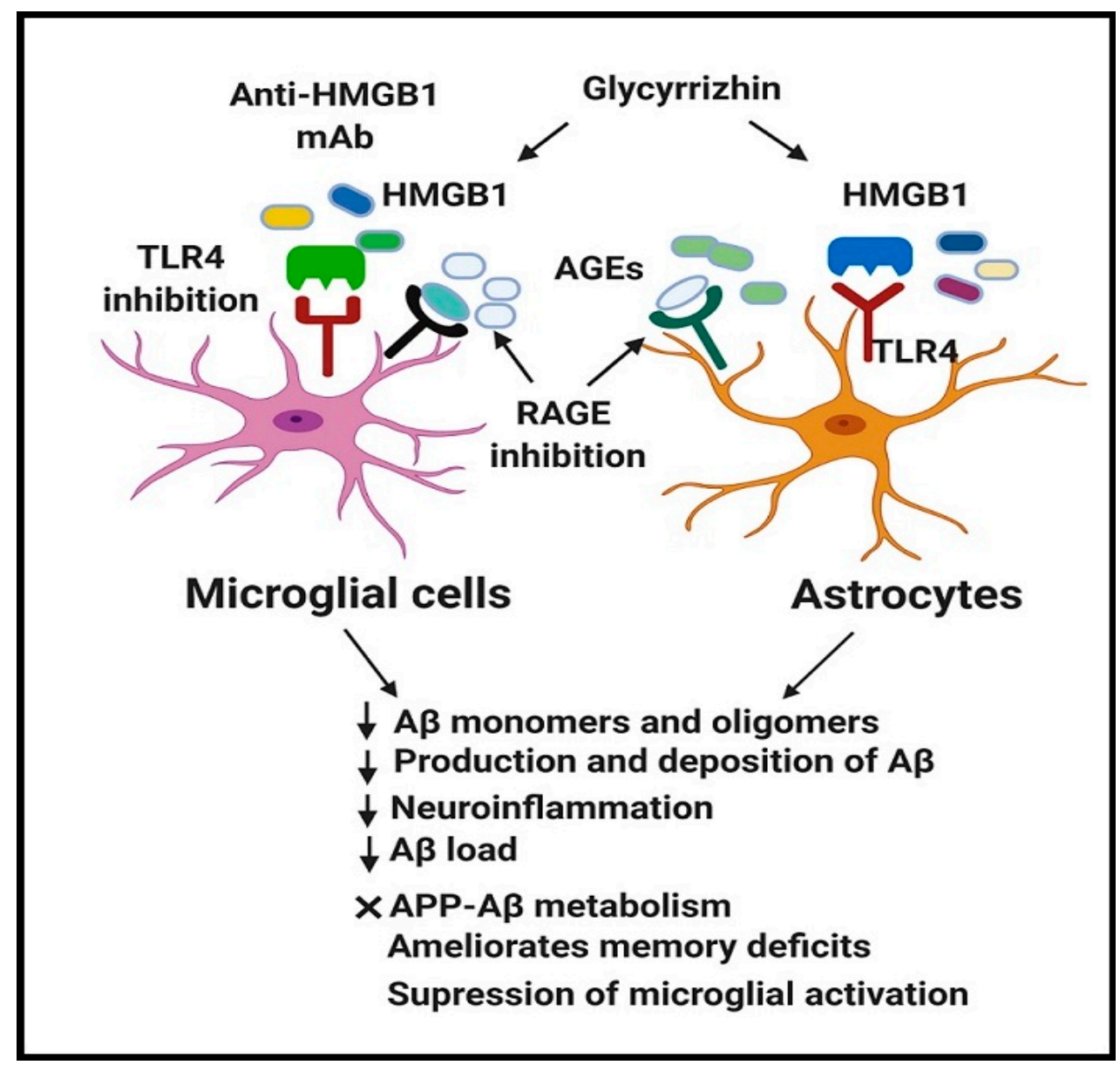

Figure 2. Beneficial effect of HMGB1, RAGE, and TLR4 inhibition in AD.

Therapeutic blockade of HMGB1, RAGE, and TLR4 in AD using their respective inhibitors demonstrated promising outcomes in modifying AD progression through inhibition of HMGB1, RAGE, and TLR4 expression. Moreover, neutralization of HMGB1, RAGE, and TLR4 leads to the decrease in $A \beta$ monomers and oligomers, suppression of abnormal APP-A $\beta$ metabolism, inhibition of neuroinflammation, reduction of $A \beta$ load (number and size of $A \beta$ deposit) and $A \beta$ production, amelioration of spatial learning and memory deficits, and suppression of microglial activation. These reflect that HMGB1, RAGE, and TLR4 might represent promising therapeutic targets against AD. AD, Alzheimer's disease; HMGB1, High mobility group box 1; RAGE, Receptor for advanced glycation end products; TLR4, Toll-like receptor 4; A $\beta$, Amyloid beta; APP, Amyloid precursor protein; AGEs, Advanced glycation end products.

However, on a broader aspect, we should acknowledge the fact that developing treatment strategies for $\mathrm{AD}$ is much complex. Also, it is worth noting that due to the multifactorial, heterogeneous, progressive, and interactive pathophysiology of $\mathrm{AD}$, there is a need for personalized combinatorial treatment that differs based on patients' medical history and disease stages [131].

The encouraging outcome of HMGB1, RAGE, and TLR4 blockade/inhibition indicates that extensive research is highly demanded to elucidate their pathogenic role in $\mathrm{AD}$, along with future clinical studies to validate their therapeutic potential. 
Table 1. Summaries of studies reporting HMGB1 targeted therapies in AD and related pathology.

\begin{tabular}{|c|c|c|c|c|c|}
\hline S.N. & Interventions & Model & Treatment Schedule & Observations & References \\
\hline 1 & $\begin{array}{l}\text { HMGB1 short hairpin } \\
\text { RNA (shRNA) }\end{array}$ & $\begin{array}{l}\mathrm{A} \beta_{25-35} \text {-induced }(25 \mu \mathrm{mol} / \mathrm{L}) \\
\text { neuroinflammation in } \\
\text { hippocampal neuron cultures }\end{array}$ & Pre-treated for $24 \mathrm{~h}$ & $\begin{array}{l}\text { - HMGB1 shRNA inhibits nuclei to cytoplasmic } \\
\text { translocation of HMGB1 after treatment with A } \beta_{25-35 .} \\
\text { HMGB1 shRNA inhibits NF-kB activity, reduced RAGE } \\
\text { and TLR4 expression and inhibited inflammatory cytokine } \\
\text { (HMGB1, IL-1 } \beta, \text { IL-6, and TNF- } \alpha \text { ) secretion after } \\
\text { A } \beta_{25-35} \text { treatment. }\end{array}$ & [18] \\
\hline 2 & $\begin{array}{c}\text { Anti-HMGB1 mAb } \\
(1 \mathrm{mg} / \mathrm{kg}, \text { S.C. injection }) \\
\text { (1 injection/week })\end{array}$ & $\begin{array}{c}\text { 5xFAD transgenic mice } \\
\text { overexpressing the mutant } \\
\text { human APP }\end{array}$ & $\begin{array}{l}\text { Administered for } \\
1-6 \text { months or 3-6 months }\end{array}$ & $\begin{array}{l}\text { - Anti-HMGB1 mAb treatment decreases the amount of } A \beta \\
\text { aggregates and the oligomers as well as enhance } A \beta \\
\text { phagocytosis by microglia. } \\
\text { Treatment with Anti-HMGB1 mAb inhibited the } \\
\text { degeneration of neurite even in the presence of } A \beta \\
\text { plaques and completely ameliorated the } \\
\text { cognitive dysfunction. }\end{array}$ & [37] \\
\hline 3 & $\begin{array}{l}\text { Glycyrrhizic acid (GA) (50 } \\
\text { and } 100 \mathrm{mg} / \mathrm{kg} \text {, I.P.) }\end{array}$ & $\begin{array}{l}\text { LPS }(250 \mu \mathrm{g} / \mathrm{kg}) \text {-induced } \\
\text { neuroinflammation and } \\
\text { cognitive impairment in the } \\
\text { C57 mice }(4-5 \text { weeks old })\end{array}$ & Once daily for 1 week & $\begin{array}{l}\text { GA treatment ameliorate LPS-induced cognitive decline } \\
\text { and neuronal damage by decreasing the escaped latency } \\
\text { in MWM test and upregulating the number of } \\
\text { Nissl-stained cells and normal neurons in the } \\
\text { hippocampus respectively. } \\
\text { Treatment with GA reduces LPS-induced } \\
\text { neuroinflammatory response in cortex and hippocampus } \\
\text { (TNF- } \alpha \text { and IL-1 } \beta \text { ). }\end{array}$ & [109] \\
\hline 4 & $\begin{array}{l}\text { Glycyrrhizin (GL) } \\
\text { (16.8 mg/kg, I.P.) }\end{array}$ & $\begin{array}{l}\text { p35\% } / \mathrm{Tg} 2576 \text { mice (p35 } \\
\text { deletion in Tg2576 mice) }\end{array}$ & $\begin{array}{l}\text { Every alternate day for } \\
1 \text { week }\end{array}$ & - GL treatment reduced neuronal cell death & [42] \\
\hline 5 & GL (30 mg/kg, orally) & $\begin{array}{l}\text { Surgery induced cognitive } \\
\text { decline in C57BL/6 mice }\end{array}$ & $\begin{array}{l}\text { Once daily for } 3 \text { days } \\
\text { pre-operatively }\end{array}$ & $\begin{array}{l}\text { GL pre-treatment reduces splenectomy surgery-induced } \\
\text { neuroinflammation (TNF- } \alpha \text {, IL-6 and IL-1 } \beta \text { ). } \\
\text { Pre-treatment with GL attenuates the increases of } \\
\text { Hippocampal A } \beta \text { levels, Tau phosphorylation and } \\
\text { HMGB1 upregulation induced splenectomy surgery. } \\
\text { - GL rescued the splenectomy surgery induced spatial } \\
\text { memory deficits as demonstrated by the shorter } \\
\text { swimming latency as well as distance in MWM test. }\end{array}$ & [110] \\
\hline
\end{tabular}


Table 1. Cont

\begin{tabular}{|c|c|c|c|c|c|}
\hline S.N. & Interventions & Model & Treatment Schedule & Observations & References \\
\hline 6 & $\begin{array}{l}\text { GL ( } 30 \text { and } 50 \mathrm{mg} / \mathrm{kg} \text {, } \\
\text { orally) }\end{array}$ & $\begin{array}{l}\text { LPS }(3 \mathrm{mg} / \mathrm{kg} \text {, I.P.)-induced } \\
\text { neuroinflammation and } \\
\text { cognitive impairment in the } \\
\text { C57BL } / 6 \text { mice }\end{array}$ & $\begin{array}{l}\text { Once a day for } 3 \text { days } \\
\text { prior to LPS injection }\end{array}$ & $\begin{array}{l}\text { GL ameliorated the LPS-induced memory deficit as } \\
\text { evident by prolonged swimming time in MWM trial. } \\
\text { GL administration reduced the markers of inflammation } \\
\text { (TNF- } \alpha \text { and IL- } 1 \beta \text { mRNA) and protein expression of } \\
\text { COX- } 2 \text { and iNOS. }\end{array}$ & [108] \\
\hline 7 & $\begin{array}{l}\text { 18 } \alpha \text {-glycyrrhetinic acid } \\
\text { (GA) }(20 \mu \mathrm{g} / \mathrm{mL})\end{array}$ & $\begin{array}{l}\text { AD nematode models (WT } \\
\text { Caenorhabditis elegans) }\end{array}$ & - & $\begin{array}{l}\text { - Administration of } 18 \alpha-\mathrm{GA} \text { increased the levels of } \\
\text { proteasome activities leading to a skinhead-1 and } \\
\text { proteasome activation-dependent life span extension. } \\
18 \alpha \text {-GA treatment reduces A } \beta \text { toxicity and reduces } \\
\text { A } \beta \text {-induced neuronal cell death. }\end{array}$ & [132] \\
\hline S.N. & Interventions & Model & Treatment Schedule & Observations & References \\
\hline 1 & $\begin{array}{l}\text { TTP488 (RAGE } \\
\text { antagonist) }\end{array}$ & $\begin{array}{c}\text { Transgenic mice } \\
\text { overexpressing APP/PS1 }\end{array}$ & $\begin{array}{l}\text { Oral treatment with } \\
\text { TTP488 starting at } \\
12 \text { months of age }\end{array}$ & $\begin{array}{l}\text { - TTP488 treatment ameliorated disease } \\
\text { progression dose-dependently. } \\
\text { Treatment with TTP488 increased in amyloid burden and } \\
\text { reduced inflammatory cytokines }\end{array}$ & [116] \\
\hline 2 & $\begin{array}{l}\text { sRAGE-mesenchymal } \\
\text { stem cells (MSCs) }\end{array}$ & $\begin{array}{c}\mathrm{A} \beta_{1-42}(5 \mu \mathrm{L} ; 200 \mu \mathrm{M}) \\
\text { peptides induced } \mathrm{AD} \text { model } \\
\text { in SD rats }\end{array}$ & $\begin{array}{l}\text { sRAGE-MSCs is } \\
\text { transplanted for } 4 \text { months }\end{array}$ & $\begin{array}{l}\text { - Treatment with sRAGE-MSC decreased apoptotic cells, } \\
\text { increased neuron survival and reduced inflammatory } \\
\text { cytokines (mRNA of TNF- } \alpha \text {, INF- } \gamma \text { and IL-1 } \beta \text { ) in A } \beta_{1-42} \\
\text { administered rats. } \\
\text { Transplanted sRAGE-MSCs showed improved survival } \\
\text { rate compared to MSCs as evidenced by elevated mRNA } \\
\text { levels of CD } 44, \text { CD90 and CD117 for sRAGE-MSCs. }\end{array}$ & [133] \\
\hline
\end{tabular}


Table 2. Cont

\begin{tabular}{|c|c|c|c|c|c|}
\hline S.N. & Interventions & Model & Treatment Schedule & Observations & References \\
\hline 3 & $\begin{array}{l}\text { Hesperidin }(20,40 \text { and } \\
80 \mathrm{mg} / \mathrm{kg})\end{array}$ & $\begin{array}{c}\text { AD like pathology in APP/PS1 } \\
\text { mice }\end{array}$ & Treatment for 90 days & $\begin{array}{l}\text { - Treatment with Hesperidin inhibited the increased RAGE } \\
\text { expression, the increased phosphorylation of IkB } \alpha \text {, } \\
\text { terminated nuclear translocation of NF-kB/p65 in the } \\
\text { cortex of APP/PS1 mice. } \\
\text { - Hesperidin reduced oxidative stress (HO-1, SOD, CAT } \\
\text { and GSH-Px) and inflammation (TNF- } \alpha, \text { CRP, MCP-1 and } \\
\text { NF- } k B \text { ) in cerebral cortex of APP/PS1 mice. } \\
\text { Treatment with Hesperidin restored learning and memory } \\
\text { dysfunction in APP/PS1 mice as evident by decreased } \\
\text { escape latency and increased staying in the target } \\
\text { quadrant in MWM trial. }\end{array}$ & [118] \\
\hline 4 & $\begin{array}{c}\text { Linguizhugan }(2.4,4.8 \text {, or } \\
1.2 \mathrm{~g} / \mathrm{kg})\end{array}$ & $\begin{array}{l}\mathrm{A} \beta \text {-induced }(10 \mu \mathrm{g}) \mathrm{AD} \\
\text { model in SD rats }\end{array}$ & $\begin{array}{l}\text { Linguizhugan treatment } \\
\text { for } 25 \text { days }\end{array}$ & $\begin{array}{l}\text { - Linguizhugan downregulated the reactive expression } \\
\text { levels of RAGE, reduced TNF- } \alpha \text {, IL-1 } \beta \text {, IL-6, A } \beta_{1-42} \text { as } \\
\text { well as inhibit MAPK and NF- } \mathrm{B} \text { signaling. } \\
\text { Linguizhugan ameliorated A } \beta \text {-induced spatial learning } \\
\text { and memory deficits in MWM trials and improves brain } \\
\text { neuronal damage as evident by increased number of } \\
\text { neurons in H\&E staining. }\end{array}$ & [117] \\
\hline 5 & $\begin{array}{l}\text { RAGE specific inhibitor } \\
\text { (FPS-ZM1, } 1 \mathrm{mg} / \mathrm{kg} / \mathrm{d}, \text { I.P.) }\end{array}$ & $\begin{array}{l}\text { Male } \mathrm{APP} \mathrm{P}^{\mathrm{sw}} / 0 \text { mice }(15 \text { to } \\
17 \text { months old) } \\
\text { overexpressing human APP }\end{array}$ & $\begin{array}{l}\text { For } 2 \text { months starting at } 8 \\
\text { or } 15 \text { months of age }\end{array}$ & $\begin{array}{l}\text { - FPS-ZM1 bind exclusively to RAGE and inhibited } \\
\text { RAGE-driven influx of circulating } A \beta_{40} \text { and } A \beta_{42} \text { into } \\
\text { the brain. } \\
\text { Treatment with FPS-ZM1 decrease activity of } \beta \text {-secretase } \\
\text { activity, A } \beta \text { production and inhibited activation of } \\
\text { microglia and the neuroinflammatory mediators (TNF- } \alpha \text {, } \\
\text { IL-1 } \beta, \text { IL-6, and CCL2). }\end{array}$ & [115] \\
\hline 6 & $\begin{array}{c}\text { DNMSR } \\
\text { (dominant-negative } \\
\text { form of RAGE lacking } \\
\text { RAGE signaling targeted } \\
\text { to microglia) }\end{array}$ & $\begin{array}{l}\text { AD mouse model carrying } \\
\text { human } \\
\text { mutation of APP (mhAPP) } \\
\text { expressing human A } \beta\end{array}$ & - & $\begin{array}{l}\text { - Inhibition of microglial RAGE prevented synaptic and } \\
\text { behavioural deficits and lowered the activation of stress } \\
\text { related kinase (p38MAPK and JNK). } \\
\text { Blocking of microglial RAGE signaling prevents } \\
\text { entorhinal cortex (EC) synaptic impairment at several } \\
\text { stages of neurodegeneration in mhAPP mice. }\end{array}$ & [134] \\
\hline
\end{tabular}


Table 2. Cont.

\begin{tabular}{|c|c|c|c|c|c|}
\hline S.N. & Interventions & Model & Treatment Schedule & Observations & References \\
\hline 7 & $\begin{array}{l}\text { Pentamidine }(0.05 \mu \mathrm{g} / \mathrm{mL}) \\
\quad(\mathrm{S} 100 \beta \text { inhibitor })\end{array}$ & $\begin{array}{l}\mathrm{A} \beta \text {-induced }(10 \mu \mathrm{g} / \mathrm{mL}) \mathrm{AD} \\
\text { in C57BL/6J mice }\end{array}$ & Per day & $\begin{array}{l}\text { Pentamidine treatment reduced the expression of GFAP, } \\
\text { S100B, and RAGE protein. } \\
\text { Treatment with Pentamidine reduces neuroinflammation } \\
\text { (NF-kB, IL-1 } \beta \text { ) and exerted neuroprotection in CA1 } \\
\text { pyramidal neurons. }\end{array}$ & [113] \\
\hline 8 & Matrine (10 and $50 \mu \mathrm{M})$ & $\begin{array}{l}\mathrm{APP} / \mathrm{PS} 1 \text { transgenic mice } \\
\text { model }\end{array}$ & & $\begin{array}{l}\text { Treatment with Matrine inhibited } \mathrm{A} \beta_{42} \text {-induced } \\
\text { cytotoxicity and repress the A } \beta / \text { RAGE signaling axis } \\
\text { in vitro in SH-SY5Y cells. } \\
\text { Matrine treatment downregulated expression of } \\
\text { pro-inflammatory mediators (NF-kB, IL-1 } \beta \text {, and TNF- } \alpha \text { ), } \\
\text { reduced A } \beta \text { deposition and ameliorated the memory } \\
\text { impairment of AD transgenic mice. }\end{array}$ & [114] \\
\hline 9 & $\begin{array}{l}\text { PF-04494700 (10 or } 20 \mathrm{mg} \text { ) } \\
\quad \text { (oral RAGE inhibitor) }\end{array}$ & $\begin{array}{l}\text { Subjects with } \\
\text { mild-to-moderate dementia of } \\
\text { AD type meeting } \\
\text { NINCDS-ADRDA criteria }\end{array}$ & $\begin{array}{l}10 \text { week randomized, double-blind, } \\
\text { placebo-controlled trial with } 2 \text { doses } \\
\text { of PF-04494700 }(10 \mathrm{mg} \text {, after a 6-day } \\
\text { loading dose of } 30 \mathrm{mg} / \mathrm{d}) \text {; and } \\
\text { PF-04494700 (20 mg, after a loading } \\
\text { dose of } 60 \mathrm{mg} / \mathrm{d}) ;\end{array}$ & $\begin{array}{l}\text { PF-04494700 treatment was safe and well-tolerated in } \\
\text { a subject. } \\
\text { PF-04494700 treatment exhibited no consistent or clinical } \\
\text { effect on plasma levels of A } \beta \text {, inflammatory biomarkers } \\
\text { (IL-6, IL-1 } \beta \text { and TGF- } \beta-1 \text { ), or secondary cognitive or } \\
\text { functional outcomes in this human trial. }\end{array}$ & [135] \\
\hline 10 & $\begin{array}{l}\text { PF-04494700 (RAGE } \\
\text { inhibitor) }\end{array}$ & $\begin{array}{c}\text { Double-blind, } \\
\text { placebo-controlled trial at } 40 \\
\text { several centre, subjects } \\
\text { assessed with AD assessment } \\
\text { scale-cognitive-subscale }\end{array}$ & $\begin{array}{l}\text { Treatment for } 18 \text { months using } 2 \\
\text { doses of PF-04494700 } \\
60 \mathrm{mg} / \text { day for } 6 \text { days, then } 20 \mathrm{mg} \\
\text { daily and } 15 \mathrm{mg} / \text { day for } 6 \text { days, then } \\
5 \mathrm{mg} \text { daily }\end{array}$ & $\begin{array}{l}\text { - High dose of PF-04494700 }(20 \mathrm{mg} / \mathrm{d}) \text { enhanced the adverse } \\
\text { effects and cognitive deficits whereas low dose of } \\
\text { PF-04494700 }(5 \mathrm{mg} / \mathrm{d}) \text { exhibited a good safety profile. }\end{array}$ & [136] \\
\hline
\end{tabular}

AD, Alzheimer's disease AD; HMGB1, High mobility group box 1; RAGE, Receptor for advanced glycation end products; TLR4, Toll-like receptor 4; A $\beta$, Amyloid beta; APP, Amyloid precursor protein; PS1, Presenilin 1; MSCs, Mesenchymal stem cells MSCs; IL, Interleukin; IBA1, ionized calcium-binding adapter molecule 1; NINCDS-ADRDA, National institute of neurological and communicative diseases and stroke/Alzheimer's disease and related disorders association; NF- $\mathrm{kB}$, Nuclear factor $\mathrm{k}$ light chain enhancer of activated B cells; CA, Cornu ammonis; CAT, Catalase; SOD, Superoxide dismutase; TNF- $\alpha$, Tumor necrosis factor- $\alpha$, TGF- $\beta 1$, Transforming growth factor- $\beta 1$; GFAP, Glial fibrillary acidic protein; MAPK, Mitogen-activated protein kinase; IL, Interleukin; iNOS, Inducible nitric oxide synthase; MWM, Morris water maze. 
Table 3. Summaries of pre-clinical studies investigating TLR4 inhibition in AD-like pathology.

\begin{tabular}{|c|c|c|c|c|c|}
\hline S.N. & Interventions & Model & Treatment Schedule & Observations & References \\
\hline 1 & $\begin{array}{l}\text { Monophosphoryl lipid A, } \\
\text { LPS-derived TLR4 agonist } \\
\text { (MPL, } 50 \mu \mathrm{g} \text {, I.P.) }\end{array}$ & $\begin{array}{l}\text { AD like pathology in } \\
\mathrm{APP}_{\text {swe }} / \mathrm{PS} 1 \text { mice }\end{array}$ & $\begin{array}{l}\text { Administered once a } \\
\text { week for } 12 \text { weeks }\end{array}$ & $\begin{array}{l}\text { - TLR4 stimulation with MPL ameliorate AD-like pathology } \\
\text { as well as stimulates the phagocytic capacity of innate } \\
\text { immune cells. } \\
\text { Treatment with MPL reduced A } \beta \text { load (number and size } \\
\text { of A } \beta \text { deposit) in the brain of APP swe/PS1 mice and } \\
\text { ameliorated cognitive decline as assessed by T-maze. }\end{array}$ & [120] \\
\hline 2 & MPL $(1 \mu \mathrm{g} / 5 \mu \mathrm{L} / \mathrm{rat})$ & $\begin{array}{c}\mathrm{A} \beta_{1-42} \text {-induced } \\
(0.075 \mu \mathrm{g} / \text { hour, I.C.V. for } \\
2 \text { weeks }) \text { AD related cognitive } \\
\text { decline in male Wistar rats }\end{array}$ & $\begin{array}{l}\text { MPL treatment for } \\
24 \text { days ( } 8 \text { injections } \\
\text { alternate } 3 \text { days) }\end{array}$ & $\begin{array}{l}\text { Early slight activation of microglia by MPL protect } \\
\text { synaptic function and improve learning and } \\
\text { memory performance. } \\
\text { MPL treatment induced dose-dependent release of TNF- } \alpha \\
\text { and CCL-3 from BV-2 cells. } \\
\text { - Treatment with MPL upregulated hippocampal } \\
\text { expression of IL-10 and TGF-1 } \beta \text {, and arginase } 1 .\end{array}$ & [126] \\
\hline 3 & Gx-50 (1 mg/kg) & $A P P$ transgenic model of $\mathrm{AD}$ & $\begin{array}{l}\text { Gx-50 administered daily } \\
\text { for } 2 \text { months at } 5 \text { months } \\
\text { of age }\end{array}$ & $\begin{array}{l}\text { - Gx-50 treatment inhibited TLR4-mediated inflammatory } \\
\text { (reduced both TLR4 mRNA and TLR4 proteins) signal } \\
\text { cascade in microglial cells and in APP-transgenic mice. } \\
\text { Gx-50 treatment inhibited the expression of TNF- } \alpha \text {, IL-1 } \beta \text {, } \\
\text { NO, PGE2, iNOS and COX-2 in A } \beta \text { treated rat microglia. }\end{array}$ & [121] \\
\hline 4 & Hesperetin (50 mg) & $\begin{array}{c}\mathrm{A} \beta_{1-42} \text {-induced } \\
(5 \mu \mathrm{L} / 5 \mathrm{~min} / \mathrm{mouse}) \mathrm{AD} \text { model } \\
\text { in }(\mathrm{C} 57 \mathrm{BL} / 6 \mathrm{~N}, \mathrm{WT}) \text { mouse }\end{array}$ & $\begin{array}{l}\text { Hesperetin }(50 \mathrm{mg}) \\
\text { treatment for } 6 \text { weeks }\end{array}$ & $\begin{array}{l}\text { - Hesperetin regulates AD-like pathology by regulating } \\
\text { APP, BACE-1, and A } \beta \text {. } \\
\text { Hesperetin treatment conferred neuroprotection via } \\
\text { inhibition of oxidative stress (decrease LPO, ROS and } \\
\text { increase Nrf2 and HO-1) neuroinflammation (decreased } \\
\text { TLR4, p-NF- } \mathrm{kB}, \mathrm{TNF}-\alpha \text {, and IL-1 } \beta \text { ), apoptotic cell death } \\
\text { (decreased Caspase- } 3 \text { and PARP-1) and cognitive } \\
\text { consolidation (MWM and Y-maze). }\end{array}$ & [123] \\
\hline 5 & MG53 (2 mg/kg) & $\begin{array}{l}\text { LPS-induced }(0.25 \mathrm{mg} / \mathrm{kg} \text {, I.P. } \\
\text { once a day for } 1 \mathrm{week}) \\
\text { neuroinflammation and } \\
\text { neurotoxicity (in vitro and } \\
\text { in vivo) in male } \\
\text { C57BL } / 6 \text { mice. }\end{array}$ & $\begin{array}{l}\text { MG53 (once a day for } 2 \\
\text { weeks) was intravenously } \\
\text { administrated through tail } \\
\text { vein one week before } \\
\text { LPS injection. }\end{array}$ & $\begin{array}{l}\text { - In the hippocampus of LPS treated mice, MG53 treatment } \\
\text { inhibited LPS-induced neuroinflammation in vivo } \\
\text { (decreases IL-1 } \beta, \text { IL-6, TLR4, p-IKB } \alpha \text { and p-NF-KB) via } \\
\text { inhibiting TLR4/NF-kB signaling. } \\
\text { Pre-treatment with MG53 ameliorated LPS induced } \\
\text { memory deficits as evident by shorter escape latency, } \\
\text { greater portion of time spent in the target quadrant in } \\
\text { MWM trail. }\end{array}$ & [124] \\
\hline
\end{tabular}


Table 3. Cont

\begin{tabular}{|c|c|c|c|c|c|}
\hline S.N. & Interventions & Model & Treatment Schedule & Observations & References \\
\hline 6 & Resveratrol & $\begin{array}{c}\text { In vitro study (RAW } 264.7 \\
\text { cells stimulated with } \\
10 \mathrm{ng} / \mathrm{mL} \text { LPS, BV-2 cells } \\
100 \mathrm{ng} / \mathrm{mL} \text { LPS, and Ba/F3 } \\
\text { cells with } 50 \mathrm{ng} / \mathrm{mL} \mathrm{LPS} \text { ) } \\
\text { In vivo study in A } \beta \text { APP/PS1 } \\
\text { transgenic mice }\end{array}$ & $\begin{array}{l}\text { Orally administered for } \\
15 \text { weeks }\end{array}$ & $\begin{array}{l}\text { - } 50 \mu \mathrm{M} \text { resveratrol treatment inhibited cytokine secretion, } \\
\text { NF- } \mathrm{B} \text { and STAT1/3 signaling LPS-stimulated BV-2 and } \\
\text { RAW } 264.7 \text { cells. } \\
\text { - Resveratrol acted upstream in the activation signaling via } \\
\text { interfering with TLR4 oligomerization upon } \\
\text { TLR4 stimulation. } \\
\text { - Resveratrol treatment reduced the number of activated } \\
\text { microglial cells surrounding amyloid plaques in } \\
\text { APP/PS1 mice. }\end{array}$ & [125] \\
\hline 7 & $\begin{array}{c}\text { Baicalin (BAI) }(103 \mathrm{mg} / \mathrm{kg} \\
\text { administered } \\
\text { intragastrically) }\end{array}$ & APP/PS1 transgenic mice & $\begin{array}{l}\text { Treated with BAI once a } \\
\text { day for } 33 \text { days }\end{array}$ & $\begin{array}{l}\text { Treatment with BAI ameliorated learning and memory } \\
\text { deficits evident by MWM and PAT and prevented } \\
\text { neuronal apoptosis (decreased CASP3 protein) in } \\
\text { APP/PS1 mice. } \\
\text { BAI suppressed microglial activation and } \\
\text { pro-inflammatory cytokine levels (mRNA levels of IL-1 } \beta \text {, } \\
\text { IL-18, and iNOS), inhibited activation of NLRP3 } \\
\text { inflammasome and the TLR4/NF- } \mathrm{B} \text { B signaling axis but did } \\
\text { not decrease A } \beta \text { deposition in APP/PS1 mice. }\end{array}$ & [122] \\
\hline
\end{tabular}


Author Contributions: Y.N.P. conceived, carried out the literature review, and drafted the manuscript. E.A., I.O., K.A., and M.F.S. re-drafted the manuscript. C.P. extensively revised the manuscript, provided critical revision and contributed to the final manuscript. All authors have read and agreed to the published version of the manuscript.

Funding: This work does not receive any sort of financial assistance from any funding agency.

Acknowledgments: Y.N.P. would like to acknowledge Monash University Malaysia for awarding with HDR Scholarship.

Conflicts of Interest: The authors declare that they have no competing interests.

\section{Abbreviations}

AD, Alzheimer's disease AD; HMGB1, High mobility group box 1; RAGE, Receptor for advanced glycation end products; TLRs, Toll-like receptors; DAMP, Damage-associated molecular patterns; APP, Amyloid precursor protein; NFTs, Neurofibrillary tangles; PHFs, Paired helical filaments; AGER, Advanced glycation end product specific receptor; PRRs, Pathogen recognition receptors; AHN, Adult hippocampal neurogenesis; NPCs, Neural progenitor cells; BBB, Blood-brain barrier; CNS, Central nervous system; PTMs, Post-translational modifications; MARCKS, Myristoylated alanine-rich C-kinase substrate; TREM2, Triggering receptor expressed on myeloid cells 2; DCs, Dendritic cells; GFAP, Glial fibrillary acidic protein; IL, Interleukin; IBA1, ionized calcium-binding adapter molecule 1; iNOS, Inducible nitric oxide synthase; NF- $\kappa B$, Nuclear factor $\kappa$ light chain enhancer of activated $B$ cells; TNF- $\alpha$, Tumor necrosis factor- $\alpha$, LPS, Lipopolysaccharide; CD, Cluster of differentiation; STAT3, Signal transducer and activator of transcription 3; NLRP3, Nod-like receptor protein 3; ICV, Intracerebroventricular; CSF, Cerebrospinal fluid; MCI, Mild cognitive impairment; LOAD, late-onset AD.

\section{References}

1. Tavana, J.P.; Rosene, M.; Jensen, N.O.; Ridge, P.G.; Kauwe, J.S.; Karch, C.M. RAB10: An Alzheimer's disease resilience locus and potential drug target. Clin. Interv. Aging 2019, 14, 73. [CrossRef] [PubMed]

2. Laurent, C.; Buée, L.; Blum, D. Tau and neuroinflammation: What impact for Alzheimer's disease and tauopathies? Biomed. J. 2018, 41, 21-33. [CrossRef] [PubMed]

3. Saido, T. Alzheimer's disease as proteolytic disorders: Anabolism and catabolism of $\beta$-amyloid. Neurobiol. Aging 1998, 19, S69-S75. [CrossRef]

4. Piaceri, I.; Nacmias, B.; Sorbi, S. Genetics of familial and sporadic Alzheimer's disease. Front. Biosci. Elite Ed. 2013, 5, 167-177. [CrossRef] [PubMed]

5. Bertram, L.; Lill, C.M.; Tanzi, R.E. The genetics of Alzheimer disease: Back to the future. Neuron 2010, 68, 270-281. [CrossRef]

6. Salomone, S.; Caraci, F.; Leggio, G.M.; Fedotova, J.; Drago, F. New pharmacological strategies for treatment of Alzheimer's disease: Focus on disease modifying drugs. Br. J. Clin. Pharmacol. 2012, 73, 504-517. [CrossRef]

7. Castellani, R.J.; Perry, G. Pathogenesis and disease-modifying therapy in Alzheimer's disease: The flat line of progress. Arch. Med. Res. 2012, 43, 694-698. [CrossRef]

8. Van Eldik, L.J.; Carrillo, M.C.; Cole, P.E.; Feuerbach, D.; Greenberg, B.D.; Hendrix, J.A.; Kennedy, M.; Kozauer, N.; Margolin, R.A.; Molinuevo, J.L. The roles of inflammation and immune mechanisms in Alzheimer's disease. Alzheimer's Dement. Transl. Res. Clin. Interv. 2016, 2, 99-109. [CrossRef]

9. Štros, M. HMGB proteins: Interactions with DNA and chromatin. Biochim. Biophys. Acta BBA Gene Regul. Mech. 2010, 1799, 101-113. [CrossRef]

10. Andersson, U.; Yang, H.; Harris, H. High-mobility group box 1 protein (HMGB1) operates as an alarmin outside as well as inside cells. In Seminars in Immunology; Academic Press: New York, NY, USA, 2018; pp. 40-48.

11. Paudel, Y.N.; Angelopoulou, E.; Piperi, C.; Balasubramaniam, V.R.; Othman, I.; Shaikh, M.F. Enlightening the role of high mobility group box 1 (HMGB1) in inflammation: Updates on receptor signalling. Eur. J. Pharmacol. 2019, 858, 172487. [CrossRef]

12. Andersson, U.; Yang, H.; Harris, H. Extracellular HMGB1 as a therapeutic target in inflammatory diseases. Expert Opin. Ther. Targets 2018, 22, 263-277. [CrossRef] [PubMed]

13. Tang, Y.; Zhao, X.; Antoine, D.; Xiao, X.; Wang, H.; Andersson, U.; Billiar, T.R.; Tracey, K.J.; Lu, B. Regulation of posttranslational modifications of HMGB1 during immune responses. Antioxid. Redox Signal. 2016, 24, 620-634. [CrossRef] [PubMed]

14. Andersson, U.; Antoine, D.; Tracey, K. Expression of Concern: The functions of HMGB 1 depend on molecular localization and post-Translational modifications. J. Intern. Med. 2014, 276, 420-424. [CrossRef] 
15. Bianchi, M.E. HMGB1 loves company. J. Leukoc. Biol. 2009, 86, 573-576. [CrossRef] [PubMed]

16. Klune, J.R.; Dhupar, R.; Cardinal, J.; Billiar, T.R.; Tsung, A. HMGB1: Endogenous danger signaling. Mol. Med. 2008, 14, 476-484. [CrossRef] [PubMed]

17. Bianchi, M.E. DAMPs, PAMPs and alarmins: All we need to know about danger. J. Leukoc. Biol. 2007, 81, 1-5. [CrossRef]

18. Nan, K.; Han, Y.; Fang, Q.; Huang, C.; Yu, L.; Ge, W.; Xiang, F.; Tao, Y.-X.; Cao, H.; Li, J. HMGB1 gene silencing inhibits neuroinflammation via down-regulation of NF- $\mathrm{KB}$ signaling in primary hippocampal neurons induced by $\mathrm{A} \beta_{25-35}$. Int. Immunopharmacol. 2019, 67, 294-301. [CrossRef]

19. Takata, K.; Kitamura, Y.; Kakimura, J.-I.; Shibagaki, K.; Tsuchiya, D.; Taniguchi, T.; Smith, M.A.; Perry, G.; Shimohama, S. Role of high mobility group protein-1 (HMG1) in amyloid- $\beta$ homeostasis. Biochem. Biophys. Res. Commun. 2003, 301, 699-703. [CrossRef]

20. Du Yan, S.; Chen, X.; Fu, J.; Chen, M.; Zhu, H.; Roher, A.; Slattery, T.; Zhao, L.; Nagashima, M.; Morser, J. RAGE and amyloid- $\beta$ peptide neurotoxicity in Alzheimer's disease. Nature 1996, 382, 685. [CrossRef]

21. Miron, J.; Picard, C.; Frappier, J.; Dea, D.; Theroux, L.; Poirier, J. TLR4 gene expression and pro-inflammatory cytokines in Alzheimer's disease and in response to hippocampal deafferentation in rodents. J. Alzheimer's Dis. 2018, 63, 1547-1556. [CrossRef]

22. Cai, Z.; Liu, N.; Wang, C.; Qin, B.; Zhou, Y.; Xiao, M.; Chang, L.; Yan, L.-J.; Zhao, B. Role of RAGE in Alzheimer's disease. Cell. Mol. Neurobiol. 2016, 36, 483-495. [CrossRef] [PubMed]

23. Walter, S.; Letiembre, M.; Liu, Y.; Heine, H.; Penke, B.; Hao, W.; Bode, B.; Manietta, N.; Walter, J.; Schulz-Schüffer, W. Role of the toll-like receptor 4 in neuroinflammation in Alzheimer's disease. Cell. Physiol. Biochem. 2007, 20, 947-956. [CrossRef] [PubMed]

24. Kinney, J.W.; Bemiller, S.M.; Murtishaw, A.S.; Leisgang, A.M.; Lamb, B.T. Inflammation as a central mechanism in Alzheimer's disease. Alzheimer's Dement. Transl. Res. Clin. Interv. 2018, 4, 575-590. [CrossRef] [PubMed]

25. Heppner, F.L.; Ransohoff, R.M.; Becher, B. Immune attack: The role of inflammation in Alzheimer disease. Nat. Rev. Neurosci. 2015, 16, 358. [CrossRef] [PubMed]

26. Chaney, A.; Williams, S.R.; Boutin, H. In vivo molecular imaging of neuroinflammation in Alzheimer's disease. J. Neurochem. 2019, 149, 438-451. [CrossRef]

27. Heneka, M.T.; O’Banion, M.K.; Terwel, D.; Kummer, M.P. Neuroinflammatory processes in Alzheimer's disease. J. Neural Transm. 2010, 117, 919-947. [CrossRef]

28. Hu, J.; Akama, K.T.; Krafft, G.A.; Chromy, B.A.; Van Eldik, L.J. Amyloid- $\beta$ peptide activates cultured astrocytes: Morphological alterations, cytokine induction and nitric oxide release. Brain Res. 1998, 785, 195-206. [CrossRef]

29. Zhu, M.; Wang, X.; Sun, L.; Schultzberg, M.; Hjorth, E. Can inflammation be resolved in Alzheimer's disease? Ther. Adv. Neurol. Disord. 2018, 11, 1756286418791107. [CrossRef]

30. Pasqualetti, G.; Brooks, D.J.; Edison, P. The role of neuroinflammation in dementias. Curr. Neurol. Neurosci. Rep. 2015, 15, 17. [CrossRef]

31. Dionisio-Santos, D.A.; Olschowka, J.A.; O’Banion, M.K. Exploiting microglial and peripheral immune cell crosstalk to treat Alzheimer's disease. J. Neuroinflamm. 2019, 16, 74. [CrossRef]

32. Chi, W.; Chen, H.; Li, F.; Zhu, Y.; Yin, W.; Zhuo, Y. HMGB1 promotes the activation of NLRP3 and caspase-8 inflammasomes via NF-kB pathway in acute glaucoma. J. Neuroinflamm. 2015, 12, 137. [CrossRef] [PubMed]

33. Fang, P.; Schachner, M.; Shen, Y.-Q. HMGB1 in development and diseases of the central nervous system. Mol. Neurobiol. 2012, 45, 499-506. [CrossRef] [PubMed]

34. Harris, H.E.; Andersson, U.; Pisetsky, D.S. HMGB1: A multifunctional alarmin driving autoimmune and inflammatory disease. Nat. Rev. Rheumatol. 2012, 8, 195. [CrossRef] [PubMed]

35. Magna, M.; Pisetsky, D.S. The role of HMGB1 in the pathogenesis of inflammatory and autoimmune diseases. Mol. Med. 2014, 20, 138-146. [CrossRef]

36. Falcão, A.S.; Carvalho, L.A.; Lidónio, G.A.; Vaz, A.R.; Lucas, S.D.; Moreira, R.; Brites, D. Dipeptidyl vinyl sulfone as a novel chemical tool to inhibit HMGB1/NLRP3-inflammasome and inflamma-miRs in A $\beta$-mediated microglial inflammation. ACS Chem. Neurosci. 2016, 8, 89-99. [CrossRef]

37. Fujita, K.; Motoki, K.; Tagawa, K.; Chen, X.; Hama, H.; Nakajima, K.; Homma, H.; Tamura, T.; Watanabe, H.; Katsuno, M. HMGB1, a pathogenic molecule that induces neurite degeneration via TLR4-MARCKS, is a potential therapeutic target for Alzheimer's disease. Sci. Rep. 2016, 6, 31895. [CrossRef] 
38. Takata, K.; Kitamura, Y.; Tsuchiya, D.; Kawasaki, T.; Taniguchi, T.; Shimohama, S. High mobility group box protein-1 inhibits microglial A $\beta$ clearance and enhances A $\beta$ neurotoxicity. J. Neurosci. Res. 2004, 78, 880-891. [CrossRef]

39. Takata, K.; Takada, T.; Ito, A.; Asai, M.; Tawa, M.; Saito, Y.; Ashihara, E.; Tomimoto, H.; Kitamura, Y.; Shimohama, S. Microglial Amyloid- $\beta 1-40$ Phagocytosis Dysfunction Is Caused by High-Mobility Group Box Protein-1: Implications for the Pathological Progression of Alzheimer's Disease. Int. J. Alzheimer's Dis. 2012, 2012, 685739. [CrossRef]

40. Lue, L.-F.; Walker, D.G.; Brachova, L.; Beach, T.G.; Rogers, J.; Schmidt, A.M.; Stern, D.M.; Du Yan, S. Involvement of microglial receptor for advanced glycation endproducts (RAGE) in Alzheimer's disease: Identification of a cellular activation mechanism. Exp. Neurol. 2001, 171, 29-45. [CrossRef]

41. Tahara, K.; Kim, H.-D.; Jin, J.-J.; Maxwell, J.A.; Li, L.; Fukuchi, K.-I. Role of toll-like receptor signalling in A $\beta$ uptake and clearance. Brain 2006, 129, 3006-3019. [CrossRef]

42. Jang, A.; Liew, H.; Kim, Y.-M.; Choi, H.; Kim, S.; Hyung Lee, S.; Ohshima, T.; Mikoshiba, K.; Suh, Y.-H. p35 deficiency accelerates HMGB-1-mediated neuronal death in the early stages of an Alzheimer's disease mouse model. Curr. Alzheimer Res. 2013, 10, 829-843. [CrossRef]

43. Tobin, M.K.; Musaraca, K.; Disouky, A.; Shetti, A.; Bheri, A.; Honer, W.G.; Kim, N.; Dawe, R.J.; Bennett, D.A.; Arfanakis, K. Human Hippocampal Neurogenesis Persists in Aged Adults and Alzheimer's Disease Patients. Cell Stem Cell 2019, 24, 974-982. [CrossRef] [PubMed]

44. Moreno-Jiménez, E.P.; Flor-García, M.; Terreros-Roncal, J.; Rábano, A.; Cafini, F.; Pallas-Bazarra, N.; Ávila, J.; Llorens-Martín, M. Adult hippocampal neurogenesis is abundant in neurologically healthy subjects and drops sharply in patients with Alzheimer's disease. Nat. Med. 2019, 25, 554. [CrossRef] [PubMed]

45. Zeng, Q.; Zheng, M.; Zhang, T.; He, G. Hippocampal neurogenesis in the APP/PS1/nestin-GFP triple transgenic mouse model of Alzheimer's disease. Neuroscience 2016, 314, 64-74. [CrossRef] [PubMed]

46. Donovan, M.H.; Yazdani, U.; Norris, R.D.; Games, D.; German, D.C.; Eisch, A.J. Decreased adult hippocampal neurogenesis in the PDAPP mouse model of Alzheimer's disease. J. Comp. Neurol. 2006, 495, 70-83. [CrossRef] [PubMed]

47. Jin, K.; Galvan, V.; Xie, L.; Mao, X.O.; Gorostiza, O.F.; Bredesen, D.E.; Greenberg, D.A. Enhanced neurogenesis in Alzheimer's disease transgenic (PDGF-APPSw, Ind) mice. Proc. Natl. Acad. Sci. USA 2004, 101, 13363-13367. [CrossRef]

48. Choi, S.H.; Tanzi, R.E. Is Alzheimer's Disease a Neurogenesis Disorder? Cell Stem Cell 2019, 25, 7-8. [CrossRef]

49. Meneghini, V.; Bortolotto, V.; Francese, M.T.; Dellarole, A.; Carraro, L.; Terzieva, S.; Grilli, M. High-mobility group box-1 protein and $\beta$-amyloid oligomers promote neuronal differentiation of adult hippocampal neural progenitors via receptor for advanced glycation end products/nuclear factor- $\mathrm{kB}$ axis: Relevance for Alzheimer's disease. J. Neurosci. 2013, 33, 6047-6059. [CrossRef]

50. Mazarati, A.; Maroso, M.; Iori, V.; Vezzani, A.; Carli, M. High-mobility group box-1 impairs memory in mice through both toll-like receptor 4 and receptor for advanced glycation end products. Exp. Neurol. 2011, 232, 143-148. [CrossRef]

51. MacLean, M.; Derk, J.; Ruiz, H.H.; Juranek, J.K.; Ramasamy, R.; Schmidt, A.M. The Receptor for Advanced Glycation End Products (RAGE) and DIAPH1: Implications for vascular and neuroinflammatory dysfunction in disorders of the central nervous system. Neurochem. Int. 2019, 126, 154-164. [CrossRef]

52. Avalos, A.M.; Kiefer, K.; Tian, J.; Christensen, S.; Shlomchik, M.; Coyle, A.J.; Marshak-Rothstein, A. RAGE-independent autoreactive B cell activation in response to chromatin and HMGB1/DNA immune complexes. Autoimmunity 2010, 43, 103-110. [CrossRef] [PubMed]

53. Daffu, G.; Shen, X.; Senatus, L.; Thiagarajan, D.; Abedini, A.; del Pozo, C.H.; Rosario, R.; Song, F.; Friedman, R.A.; Ramasamy, R. RAGE suppresses ABCG1-mediated macrophage cholesterol efflux in diabetes. Diabetes 2015, 64, 4046-4060. [CrossRef] [PubMed]

54. Dumitriu, I.E.; Baruah, P.; Bianchi, M.E.; Manfredi, A.A.; Rovere-Querini, P. Requirement of HMGB1 and RAGE for the maturation of human plasmacytoid dendritic cells. Eur. J. Immunol. 2005, 35, 2184-2190. [CrossRef] [PubMed]

55. Moser, B.; Szabolcs, M.; Ankersmit, H.; Lu, Y.; Qu, W.; Weinberg, A.; Herold, K.; Schmidt, A. Blockade of RAGE suppresses alloimmune reactions in vitro and delays allograft rejection in murine heart transplantation. Am. J. Transplant. 2007, 7, 293-302. [CrossRef] 
56. Chavakis, T.; Bierhaus, A.; Al-Fakhri, N.; Schneider, D.; Witte, S.; Linn, T.; Nagashima, M.; Morser, J.; Arnold, B.; Preissner, K.T. The pattern recognition receptor (RAGE) is a counterreceptor for leukocyte integrins: A novel pathway for inflammatory cell recruitment. J. Exp. Med. 2003, 198, 1507-1515. [CrossRef]

57. Hudson, B.I.; Lippman, M.E. Targeting RAGE signaling in inflammatory disease. Annu. Rev. Med. 2018, 69, 349-364. [CrossRef]

58. Juranek, J.; Ray, R.; Banach, M.; Rai, V. Receptor for advanced glycation end-products in neurodegenerative diseases. Rev. Neurosci. 2015, 26, 691-698. [CrossRef]

59. Yan, S.D.; Bierhaus, A.; Nawroth, P.P.; Stern, D.M. RAGE and Alzheimer's disease: A progression factor for amyloid- $\beta$-induced cellular perturbation? J. Alzheimer's Dis. 2009, 16, 833-843. [CrossRef]

60. Deane, R.; Du Yan, S.; Submamaryan, R.K.; LaRue, B.; Jovanovic, S.; Hogg, E.; Welch, D.; Manness, L.; Lin, C.; $\mathrm{Yu}, \mathrm{J}$. RAGE mediates amyloid- $\beta$ peptide transport across the blood-brain barrier and accumulation in brain. Nat. Med. 2003, 9, 907. [CrossRef]

61. Srikanth, V.; Maczurek, A.; Phan, T.; Steele, M.; Westcott, B.; Juskiw, D.; Münch, G. Advanced glycation endproducts and their receptor RAGE in Alzheimer's disease. Neurobiol. Aging 2011, 32, 763-777. [CrossRef]

62. Chaney, M.O.; Stine, W.B.; Kokjohn, T.A.; Kuo, Y.-M.; Esh, C.; Rahman, A.; Luehrs, D.C.; Schmidt, A.M.; Stern, D.; Du Yan, S. RAGE and amyloid beta interactions: Atomic force microscopy and molecular modeling. Biochim. Biophys. Acta BBA Mol. Basis Dis. 2005, 1741, 199-205. [CrossRef]

63. Xu, X.-Y.; Deng, C.-Q.; Wang, J.; Deng, X.-J.; Xiao, Q.; Li, Y.; He, Q.; Fan, W.-H.; Quan, F.-Y.; Zhu, Y.-P. Plasma levels of soluble receptor for advanced glycation end products in Alzheimer's disease. Int. J. Neurosci. 2017, 127, 454-458. [CrossRef] [PubMed]

64. Miller, M.C.; Tavares, R.; Johanson, C.E.; Hovanesian, V.; Donahue, J.E.; Gonzalez, L.; Silverberg, G.D.; Stopa, E.G. Hippocampal RAGE immunoreactivity in early and advanced Alzheimer's disease. Brain Res. 2008, 1230, 273-280. [CrossRef]

65. Arancio, O.; Zhang, H.P.; Chen, X.; Lin, C.; Trinchese, F.; Puzzo, D.; Liu, S.; Hegde, A.; Yan, S.F.; Stern, A. RAGE potentiates $A \beta$-induced perturbation of neuronal function in transgenic mice. EMBO J. 2004, 23, 4096-4105. [CrossRef] [PubMed]

66. Fang, F.; Lue, L.-F.; Yan, S.; Xu, H.; Luddy, J.S.; Chen, D.; Walker, D.G.; Stern, D.M.; Yan, S.; Schmidt, A.M. RAGE-dependent signaling in microglia contributes to neuroinflammation, $\mathrm{A} \beta$ accumulation, and impaired learning/memory in a mouse model of Alzheimer's disease. FASEB J. 2010, 24, 1043-1055. [CrossRef] [PubMed]

67. Fang, F.; Yu, Q.; Arancio, O.; Chen, D.; Gore, S.S.; Yan, S.S.; Yan, S.F. RAGE mediates A $\beta$ accumulation in a mouse model of Alzheimer's disease via modulation of $\beta$-and $\gamma$-secretase activity. Hum. Mol. Genet. 2018, 27, 1002-1014. [CrossRef]

68. Kang, J.Y.; Lee, J.-O. Structural biology of the Toll-like receptor family. Annu. Rev. Biochem. 2011, 80, 917-941. [CrossRef]

69. Bode, J.G.; Ehlting, C.; Häussinger, D. The macrophage response towards LPS and its control through the p38MAPK-STAT3 axis. Cell. Signal. 2012, 24, 1185-1194. [CrossRef]

70. Kurt-Jones, E.A.; Popova, L.; Kwinn, L.; Haynes, L.M.; Jones, L.P.; Tripp, R.A.; Walsh, E.E.; Freeman, M.W.; Golenbock, D.T.; Anderson, L.J. Pattern recognition receptors TLR4 and CD14 mediate response to respiratory syncytial virus. Nat. Immunol. 2000, 1, 398. [CrossRef]

71. Vaure, C.; Liu, Y. A comparative review of toll-like receptor 4 expression and functionality in different animal species. Front. Immunol. 2014, 5, 316. [CrossRef]

72. Le Page, A.; Dupuis, G.; Frost, E.H.; Larbi, A.; Pawelec, G.; Witkowski, J.M.; Fulop, T. Role of the peripheral innate immune system in the development of Alzheimer's disease. Exp. Gerontol. 2018, 107, 59-66. [CrossRef] [PubMed]

73. Reed-Geaghan, E.G.; Savage, J.C.; Hise, A.G.; Landreth, G.E. CD14 and toll-like receptors 2 and 4 are required for fibrillar A $\beta$-stimulated microglial activation. J. Neurosci. 2009, 29, 11982-11992. [CrossRef] [PubMed]

74. Ajit, D. Toll-like receptors 2 and 4 mediate Abeta (1-42) activation of the innate immune response in a human monocytic cell line. J. Neurochem. 2008, 104, 524-533.

75. Jin, J.-J.; Kim, H.-D.; Maxwell, J.A.; Li, L.; Fukuchi, K.-I. Toll-like receptor 4-dependent upregulation of cytokines in a transgenic mouse model of Alzheimer's disease. J. Neuroinflamm. 2008, 5, 23. [CrossRef] [PubMed] 
76. Long, H.; Zhong, G.; Wang, C.; Zhang, J.; Zhang, Y.; Luo, J.; Shi, S. TREM2 Attenuates A $\beta 1-42-M e d i a t e d$ Neuroinflammation in BV-2 Cells by Downregulating TLR Signaling. Neurochem. Res. 2019, 44, 1830-1839. [CrossRef] [PubMed]

77. Ito, H.; Hamerman, J.A. TREM-2, triggering receptor expressed on myeloid cell-2, negatively regulates TLR responses in dendritic cells. Eur. J. Immunol. 2012, 42, 176-185. [CrossRef]

78. Zhou, J.; Yu, W.; Zhang, M.; Tian, X.; Li, Y.; Lü, Y. Imbalance of Microglial TLR4/TREM2 in LPS-Treated APP/PS1 Transgenic Mice: A Potential Link Between Alzheimer's Disease and Systemic Inflammation. Neurochem. Res. 2019, 44, 1138-1151. [CrossRef]

79. Song, M.; Jin, J.; Lim, J.-E.; Kou, J.; Pattanayak, A.; Rehman, J.A.; Kim, H.-D.; Tahara, K.; Lalonde, R.; Fukuchi, K.-I. TLR4 mutation reduces microglial activation, increases A $\beta$ deposits and exacerbates cognitive deficits in a mouse model of Alzheimer's disease. J. Neuroinflamm. 2011, 8, 92. [CrossRef]

80. Go, M.; Kou, J.; Lim, J.-E.; Yang, J.; Fukuchi, K.-I. Microglial response to LPS increases in wild-type mice during aging but diminishes in an Alzheimer's mouse model: Implication of TLR4 signaling in disease progression. Biochem. Biophys. Res. Commun. 2016, 479, 331-337. [CrossRef]

81. Qin, Y.; Liu, Y.; Hao, W.; Decker, Y.; Tomic, I.; Menger, M.D.; Liu, C.; Fassbender, K. Stimulation of TLR4 Attenuates Alzheimer's Disease-Related Symptoms and Pathology in Tau-Transgenic Mice. J. Immunol. 2016, 197, 3281-3292. [CrossRef]

82. Hickman, S.E.; El Khoury, J. TREM2 and the neuroimmunology of Alzheimer's disease. Biochem. Pharmacol. 2014, 88, 495-498. [CrossRef] [PubMed]

83. Tricker, E.; Cheng, G. With a little help from my friends: Modulation of phagocytosis through TLR activation. Cell Res. 2008, 18, 711. [CrossRef] [PubMed]

84. Mackenzie, I.R.; Hao, C.; Munoz, D.G. Role of microglia in senile plaque formation. Neurobiol. Aging 1995, 16, 797-804. [CrossRef]

85. Sheng, J.G.; Bora, S.H.; Xu, G.; Borchelt, D.R.; Price, D.L.; Koliatsos, V.E. Lipopolysaccharide-inducedneuroinflammation increases intracellular accumulation of amyloid precursor protein and amyloid $\beta$ peptide in APPswe transgenic mice. Neurobiol. Dis. 2003, 14, 133-145. [CrossRef]

86. Boutajangout, A.; Wisniewski, T. The innate immune system in Alzheimer's disease. Int. J. Cell Biol. 2013, 2013, 576383. [CrossRef]

87. Morgan, A.R.; Touchard, S.; Leckey, C.; O’Hagan, C.; Nevado-Holgado, A.J.; Barkhof, F.; Bertram, L.; Blin, O.; Bos, I.; Dobricic, V. Inflammatory biomarkers in Alzheimer's disease plasma. Alzheimer's Dement. 2019, 15, 776-787. [CrossRef]

88. Bayer, A.J. The role of biomarkers and imaging in the clinical diagnosis of dementia. Age Ageing 2018, 47, 641-643. [CrossRef]

89. Molinuevo, J.L.; Gispert, J.D.; Dubois, B.; Heneka, M.T.; Lleo, A.; Engelborghs, S.; Pujol, J.; de Souza, L.C.; Alcolea, D.; Jessen, F. The AD-CSF-index discriminates Alzheimer's disease patients from healthy controls: A validation study. J. Alzheimer's Dis. 2013, 36, 67-77. [CrossRef]

90. Ritchie, C.; Smailagic, N.; Noel-Storr, A.H.; Ukoumunne, O.; Ladds, E.C.; Martin, S. CSF tau and the CSF tau/ABeta ratio for the diagnosis of Alzheimer's disease dementia and other dementias in people with mild cognitive impairment (MCI). Cochrane Database Syst. Rev. 2017. [CrossRef]

91. Zetterberg, H.; Schott, J.M. Biomarkers for Alzheimer's disease beyond amyloid and tau. Nat. Med. 2019, 25, 201. [CrossRef]

92. Festoff, B.W.; Sajja, R.K.; van Dreden, P.; Cucullo, L. HMGB1 and thrombin mediate the blood-brain barrier dysfunction acting as biomarkers of neuroinflammation and progression to neurodegeneration in Alzheimer's disease. J. Neuroinflamm. 2016, 13, 194. [CrossRef] [PubMed]

93. Sasaki, N.; Toki, S.; Chowei, H.; Saito, T.; Nakano, N.; Hayashi, Y.; Takeuchi, M.; Makita, Z. Immunohistochemical distribution of the receptor for advanced glycation end products in neurons and astrocytes in Alzheimer's disease. Brain Res. 2001, 888, 256-262. [CrossRef]

94. Mruthinti, S.; Buccafusco, J.J.; Hill, W.D.; Waller, J.L.; Jackson, T.W.; Zamrini, E.Y.; Schade, R.F. Autoimmunity in Alzheimer's disease: Increased levels of circulating IgGs binding A $\beta$ and RAGE peptides. Neurobiol. Aging 2004, 25, 1023-1032. [CrossRef] [PubMed]

95. Jeynes, B.; Provias, J. Evidence for altered LRP/RAGE expression in Alzheimer lesion pathogenesis. Curr. Alzheimer Res. 2008, 5, 432-437. [CrossRef] [PubMed] 
96. Donahue, J.E.; Flaherty, S.L.; Johanson, C.E.; Duncan, J.A.; Silverberg, G.D.; Miller, M.C.; Tavares, R.; Yang, W.; Wu, Q.; Sabo, E. RAGE, LRP-1, and amyloid-beta protein in Alzheimer's disease. Acta Neuropathol. 2006, 112, 405-415. [CrossRef]

97. Emanuele, E.; D’Angelo, A.; Tomaino, C.; Binetti, G.; Ghidoni, R.; Politi, P.; Bernardi, L.; Maletta, R.; Bruni, A.C.; Geroldi, D. Circulating levels of soluble receptor for advanced glycation end products in Alzheimer disease and vascular dementia. Arch. Neurol. 2005, 62, 1734-1736. [CrossRef]

98. Zhang, W.; Wang, L.-Z.; Yu, J.-T.; Chi, Z.-F.; Tan, L. Increased expressions of TLR2 and TLR4 on peripheral blood mononuclear cells from patients with Alzheimer's disease. J. Neurol. Sci. 2012, 315, 67-71. [CrossRef]

99. Kilic, U.; Elibol, B.; Uysal, O.; Kilic, E.; Yulug, B.; Sakul, A.S.; Yildiz, G.B. Specific alterations in the circulating levels of the SIRT1, TLR4, and IL7 proteins in patients with dementia. Exp. Gerontol. 2018, 111, $203-209$. [CrossRef]

100. Balistreri, C.; Grimaldi, M.; Chiappelli, M.; Licastro, F.; Castiglia, L.; Listì, F.; Vasto, S.; Lio, D.; Caruso, C.; Candore, G. Association between the polymorphisms of TLR4 and CD14 genes and Alzheimer's disease. Curr. Pharm. Des. 2008, 14, 2672-2677. [CrossRef]

101. Musumeci, D.; Roviello, G.N.; Montesarchio, D. An overview on HMGB1 inhibitors as potential therapeutic agents in HMGB1-related pathologies. Pharmacol. Ther. 2014, 141, 347-357. [CrossRef]

102. Nishibori, M.; Mori, S.; Takahashi, H.K. Anti-HMGB1 monoclonal antibody therapy for a wide range of CNS and PNS diseases. J. Pharmacol. Sci. 2019, 140, 94-101. [CrossRef] [PubMed]

103. Paudel, Y.N.; Angelopoulou, E.; Semple, B.; Piperi, C.; Othman, I.; Shaikh, M.F. Potential neuroprotective effect of the HMGB1 inhibitor Glycyrrhizin in neurological disorders. ACS Chem. Neurosci. 2020. [CrossRef] [PubMed]

104. Okuma, Y.; Liu, K.; Wake, H.; Liu, R.; Nishimura, Y.; Hui, Z.; Teshigawara, K.; Haruma, J.; Yamamoto, Y.; Yamamoto, H. Glycyrrhizin inhibits traumatic brain injury by reducing HMGB1-RAGE interaction. Neuropharmacology 2014, 85, 18-26. [CrossRef] [PubMed]

105. Li, Y.J.; Wang, L.; Zhang, B.; Gao, F.; Yang, C.M. Glycyrrhizin, an HMGB1 inhibitor, exhibits neuroprotective effects in rats after lithium-pilocarpine-induced status epilepticus. J. Pharm. Pharmacol. 2019, 71, 390-399. [CrossRef] [PubMed]

106. Webster, K.M.; Shultz, S.R.; Ozturk, E.; Dill, L.K.; Sun, M.; Casillas-Espinosa, P.; Jones, N.C.; Crack, P.J.; O'Brien, T.J.; Semple, B.D. Targeting high-mobility group box protein 1 (HMGB1) in pediatric traumatic brain injury: Chronic neuroinflammatory, behavioral, and epileptogenic consequences. Exp. Neurol. 2019, 320, 112979. [CrossRef]

107. Santoro, M.; Maetzler, W.; Stathakos, P.; Martin, H.L.; Hobert, M.A.; Rattay, T.W.; Gasser, T.; Forrester, J.V.; Berg, D.; Tracey, K.J. In-vivo evidence that high mobility group box 1 exerts deleterious effects in the 1-methyl-4-phenyl-1,2,3,6-tetrahydropyridine model and Parkinson's disease which can be attenuated by glycyrrhizin. Neurobiol. Dis. 2016, 91, 59-68. [CrossRef]

108. Song, J.-H.; Lee, J.-W.; Shim, B.; Lee, C.-Y.; Choi, S.; Kang, C.; Sohn, N.-W.; Shin, J.-W. Glycyrrhizin alleviates neuroinflammation and memory deficit induced by systemic lipopolysaccharide treatment in mice. Molecules 2013, 18, 15788-15803. [CrossRef]

109. Liu, W.; Huang, S.; Li, Y.; Zhang, K.; Zheng, X. Suppressive effect of glycyrrhizic acid against lipopolysaccharide-induced neuroinflammation and cognitive impairment in C57 mice via toll-like receptor 4 signaling pathway. Food Nutr. Res. 2019, 63. [CrossRef]

110. Chen, X.; Hua, H.-P.; Liang, L.; Liu, L.-J. The oral pretreatment of glycyrrhizin prevents surgery-induced cognitive impairment in aged mice by reducing neuroinflammation and Alzheimer's-related pathology via HMGB1 inhibition. J. Mol. Neurosci. 2017, 63, 385-395.

111. Yang, H.; Wang, H.; Chavan, S.S.; Andersson, U. High mobility group box protein 1 (HMGB1): The prototypical endogenous danger molecule. Mol. Med. 2015, 21, S6-S12. [CrossRef]

112. Balducci, C.; Forloni, G. Novel targets in Alzheimer's disease: A special focus on microglia. Pharmacol. Res. 2018, 130, 402-413. [CrossRef] [PubMed]

113. Cirillo, C.; Capoccia, E.; Iuvone, T.; Cuomo, R.; Sarnelli, G.; Steardo, L.; Esposito, G. S100B inhibitor pentamidine attenuates reactive gliosis and reduces neuronal loss in a mouse model of Alzheimer's disease. Biomed. Res. Int. 2015, 2015, 508342. [CrossRef] [PubMed] 
114. Cui, L.; Cai, Y.; Cheng, W.; Liu, G.; Zhao, J.; Cao, H.; Tao, H.; Wang, Y.; Yin, M.; Liu, T. A novel, multi-target natural drug candidate, matrine, improves cognitive deficits in Alzheimer's disease transgenic mice by inhibiting A $\beta$ aggregation and blocking the RAGE/A $\beta$ axis. Mol. Neurobiol. 2017, 54, 1939-1952. [CrossRef] [PubMed]

115. Deane, R.; Singh, I.; Sagare, A.P.; Bell, R.D.; Ross, N.T.; LaRue, B.; Love, R.; Perry, S.; Paquette, N.; Deane, R.J. A multimodal RAGE-specific inhibitor reduces amyloid $\beta$-mediated brain disorder in a mouse model of Alzheimer disease. J. Clin. Investig. 2012, 122, 1377-1392. [CrossRef]

116. Kostura, M.J.; Kindy, M.S.; Burstein, A.; Valcarce, C.; Polisetti, D.; Andrews, R.; Mjalli, A.M. Efficacy of Rage Antagonists in Murine Model of Alzheimer's Disease. Alzheimer's Dement. J. Alzheimer's Assoc. 2014, 10, P638-P639. [CrossRef]

117. Hu, Q.; Yu, B.; Chen, Q.; Wang, Y.; Ling, Y.; Sun, S.; Shi, Y.; Zhou, C. Effect of Linguizhugan decoction on neuroinflammation and expression disorder of the amyloid $\beta$-related transporters RAGE and LRP-1 in a rat model of Alzheimer's disease. Mol. Med. Rep. 2018, 17, 827-834. [CrossRef]

118. Hong, Y.; An, Z. Hesperidin attenuates learning and memory deficits in APP/PS1 mice through activation of Akt/Nrf2 signaling and inhibition of RAGE/NF-kB signaling. Arch. Pharm. Res. 2018, 41, 655-663. [CrossRef]

119. Yousefi, N.; Sotoodehnejadnematalahi, F.; Heshmati-Fakhr, N.; Sayyah, M.; Hoseini, M.; Ghassemi, S.; Aliakbari, S.; Pourbadie, H.G. Prestimulation of Microglia Through TLR4 Pathway Promotes Interferon Beta Expression in a Rat Model of Alzheimer's Disease. J. Mol. Neurosci. 2019, 67, 495-503. [CrossRef]

120. Michaud, J.-P.; Hallé, M.; Lampron, A.; Thériault, P.; Préfontaine, P.; Filali, M.; Tribout-Jover, P.; Lanteigne, A.-M.; Jodoin, R.; Cluff, C. Toll-like receptor 4 stimulation with the detoxified ligand monophosphoryl lipid A improves Alzheimer's disease-related pathology. Proc. Natl. Acad. Sci. USA 2013, 110, 1941-1946. [CrossRef]

121. Shi, S.; Liang, D.; Chen, Y.; Xie, Y.; Wang, Y.; Wang, L.; Wang, Z.; Qiao, Z. Gx-50 reduces $\beta$-amyloid-induced TNF- $\alpha$, IL-1 $\beta$, NO, and PGE2 expression and inhibits NF-kB signaling in a mouse model of Alzheimer's disease. Eur. J. Immunol. 2016, 46, 665-676. [CrossRef]

122. Jin, X.; Liu, M.Y.; Zhang, D.F.; Zhong, X.; Du, K.; Qian, P.; Yao, W.F.; Gao, H.; Wei, M.J. Baicalin mitigates cognitive impairment and protects neurons from microglia-mediated neuroinflammation via suppressing NLRP 3 inflammasomes and TLR 4/NF-кB signaling pathway. CNS Neurosci. Ther. 2019, 25, 575-590. [CrossRef] [PubMed]

123. Ikram, M.; Muhammad, T.; Rehman, S.U.; Khan, A.; Jo, M.G.; Ali, T.; Kim, M.O. Hesperetin confers neuroprotection by regulating Nrf2/TLR4/NF-kB signaling in an A $\beta$ mouse model. Mol. Neurobiol. 2019, 6, 6293-6309. [CrossRef] [PubMed]

124. Guan, F.; Zhou, X.; Li, P.; Wang, Y.; Liu, M.; Li, F.; Cui, Y.; Huang, T.; Yao, M.; Zhang, Y. MG53 attenuates lipopolysaccharide-induced neurotoxicity and neuroinflammation via inhibiting TLR4/NF- $\mathrm{B}$ pathway in vitro and in vivo. Prog. Neuro-Psychopharmacol. Biol. Psychiatry 2019, 95, 109684. [CrossRef] [PubMed]

125. Capiralla, H.; Vingtdeux, V.; Zhao, H.; Sankowski, R.; Al-Abed, Y.; Davies, P.; Marambaud, P. Resveratrol mitigates lipopolysaccharide-and A $\beta$-mediated microglial inflammation by inhibiting the TLR4/NF-KB/STAT signaling cascade. J. Neurochem. 2012, 120,461-472. [CrossRef]

126. Pourbadie,H.G.; Sayyah, M.; Khoshkholgh-Sima, B.; Choopani, S.; Nategh, M.; Motamedi, F.; Shokrgozar, M.A. Early minor stimulation of microglial TLR2 and TLR4 receptors attenuates Alzheimer's disease-related cognitive deficit in rats: Behavioral, molecular, and electrophysiological evidence. Neurobiol. Aging 2018, 70, 203-216. [CrossRef]

127. Querfurth, H.W.; LaFerla, F.M. Mechanisms of disease. N. Engl. J. Med. 2010, 362, 329-344. [CrossRef]

128. Lahiri, D.K. Lessons from Alzheimer's Disease (AD) Clinical Trials: Instead of "A-Drug", AD-D prevention to Avert AD. Curr. Alzheimer Res. 2019, 16, 279-280. [CrossRef]

129. McGeer, P.L.; McGeer, E.G. Inflammation, autotoxicity and Alzheimer disease. Neurobiol. Aging 2001, 22, 799-809. [CrossRef]

130. McGeer, P.L.; McGeer, E.G. Local neuroinflammation and the progression of Alzheimer's disease. J. Neurovirol. 2002, 8, 529-538. [CrossRef]

131. Hampel, H.; Mesulam, M.-M.; Cuello, A.C.; Farlow, M.R.; Giacobini, E.; Grossberg, G.T.; Khachaturian, A.S.; Vergallo, A.; Cavedo, E.; Snyder, P.J. The cholinergic system in the pathophysiology and treatment of Alzheimer's disease. Brain 2018, 141, 1917-1933. [CrossRef] 
132. Papaevgeniou, N.; Sakellari, M.; Jha, S.; Tavernarakis, N.; Holmberg, C.I.; Gonos, E.S.; Chondrogianni, N. $18 \alpha$-Glycyrrhetinic acid proteasome activator decelerates aging and Alzheimer's disease progression in caenorhabditis elegans and neuronal cultures. Antioxid. Redox Signal. 2016, 25, 855-869. [CrossRef] [PubMed]

133. Oh, S.; Son, M.; Choi, J.; Lee, S.; Byun, K. sRAGE prolonged stem cell survival and suppressed RAGE-related inflammatory cell and T lymphocyte accumulations in an Alzheimer's disease model. Biochem. Biophys. Res. Commun. 2018, 495, 807-813. [CrossRef] [PubMed]

134. Criscuolo, C.; Fontebasso, V.; Middei, S.; Stazi, M.; Ammassari-Teule, M.; Yan, S.S.; Origlia, N. Entorhinal Cortex dysfunction can be rescued by inhibition of microglial RAGE in an Alzheimer's disease mouse model. Sci. Rep. 2017, 7, 42370. [CrossRef] [PubMed]

135. Sabbagh, M.N.; Agro, A.; Bell, J.; Aisen, P.S.; Schweizer, E.; Galasko, D. PF-04494700, an oral inhibitor of receptor for advanced glycation end products (RAGE), in Alzheimer's disease. Alzheimer Dis. Assoc. Disord. 2011, 25, 206. [CrossRef]

136. Galasko, D.; Bell, J.; Mancuso, J.Y.; Kupiec, J.W.; Sabbagh, M.N.; van Dyck, C.; Thomas, R.G.; Aisen, P.S. Clinical trial of an inhibitor of RAGE-A $\beta$ interactions in Alzheimer disease. Neurology 2014, 82, 1536-1542. [CrossRef]

(C) 2020 by the authors. Licensee MDPI, Basel, Switzerland. This article is an open access article distributed under the terms and conditions of the Creative Commons Attribution (CC BY) license (http://creativecommons.org/licenses/by/4.0/). 